\title{
ALGUNS ASPETOS SOBRE O DIREITO DISCIPLINAR LABORAL ${ }^{1}$
}

\author{
Helena Salazar*
}

\section{O Direito disciplinar laboral}

\section{A infraç̧ão disciplinar: conceito e limites}

$\mathrm{Na}$ perspectiva sancionatória, a mais evidente faceta do poder disciplinar, este serve para 0 empregador aplicar sanções em face das infracções cometidas pelo trabalhador.

0 aspecto mais complexo do exercício da acção disciplinar do empregador, deriva, em parte, da falta de conceptualização e de tipificação dos comportamentos do trabalhador que são considerados infracção disciplinar².

Com efeito, nem o Código do Trabalho nem as diversas leis que o antecederam definiram infracção disciplinar, tendência também evidenciada por outros ordenamentos laborais. Diferentemente, do que sucede, por exemplo, relativamente às relações de emprego público, em que o legislador optou por apresentar um conceito, ainda que genérico de infracção ${ }^{3}$.

A tarefa de construir e limitar o conceito tem sido especialmente difícil, em parte também porque os deveres que a lei dirige ao trabalhador são meramente exemplificativos, cfr. artigo $128 .^{\circ}$ alíneas a) a j] do n. ${ }^{0} 1$ CT. Não sendo portanto possível fazer corresponder os comportamentos violadores dos deveres do trabalhador com as infracções eventualmente praticadas. Neste quadro tem sido a doutrina e em especial, a jurisprudência que tem balizado o conceito através da resolução dos casos que é chamada a decidir, contribuindo dessa forma para o preenchimento do conceito e para a caracterização dos comportamentos qualificáveis como infracções disciplinares ${ }^{4}$. De notar que os casos que chegam a juízo destinam-se essencialmente, a apreciar a existência de um comportamento infractor no sentido de saber se existe justa causa para despedir o trabalhador, referiremos os contributos da jurisprudência nessa parte do nosso trabalho.

\footnotetext{
${ }^{1}$ Este texto corresponde ao segundo capítulo do trabalho apresentado no Instituto Politécnico do Porto para obtenção do título de especialista em Direito, em Fevereiro de 2015.

* Professora Adjunta do Instituto Superior de Contabilidade e Administração do Porto (ISCAP/IPP). Advogada. Mestre em Direito.

${ }^{2}$ Tal como considera NUNO ABRANCHES PINTO, Instituto Disciplinar Laboral, Coimbra Editora, Coimbra, 2009, p. 49 e ss.

${ }^{3} 0$ Estatuto Disciplinar dos Trabalhadores que exercem Funções Públicas, aprovado pelo DL 58/2008 de 9 de Setembro, no artigo $3 .{ }^{\circ}$ n. ${ }^{\circ} 1$ define infraç̧ão como o comportamento do trabalhador por acção ou por omissão, ainda que meramente culposo, que viole os deveres gerais ou especiais inerentes à função que exerce.

${ }^{4}$ Sobre o tema vejam-se, entre outros, os seguintes acórdãos: Ac. STJ de 23 de Novembro de 2011, processo n. ${ }^{\circ}$ 318/07.1TFAR. E1.S1, disponível em www.dgsi.pt; Ac. STJ de 25 de Janeiro de 2012, processo n. ${ }^{\circ}$ 268/04.3TTLSB.L1.S1, disponível em www.dgsi.pt; Ac. STJ de 12 de Setembro de 2012, processo n. ${ }^{\circ}$ 492/08.0TTLMG.P1.S1, disponível em www.dgsi.pt; Ac. STJ de 04 de Julho de 2013 processo n. ${ }^{\circ}$ 7583/11.8T2SNT.L1.S1, disponível em www.dgsi.pt e o Ac. RP de 22 de Outubro de 2013, processo n. ${ }^{\circ}$ 318/07.1TTFAR.E1.S1 disponível em www.dgsi.pt.
} 
A contribuição da doutrina para preencher o conceito de infracção disciplinar, surge por analogia ao conceito de justa causa previsto no artigo $351 .^{\circ} \mathrm{CT}$. Assim são propostos os seguintes elementos: a existência de um comportamento do trabalhador (por acção ou omissão), que seja ilícito e culposo. Comportamento esse, que pelo facto de o trabalhador ser responsável, Ihe possa ser imputável a título de dolo ou negligência. Trata-se todavia de um comportamento merecedor de censura, independentemente de provocar danos ao empregador.

Como a propósito da justa causa referiremos, o dano não é um elemento essencial para que exista infracção disciplinar ${ }^{5}$.

Sucede porém, que a omissão legislativa evidencia diversas dificuldades. Por um lado, deixa ao empregador alguma liberdade de determinar os comportamentos que considera objecto de sanção, e por outro, as actuações que podem configurar a existência de infracção podem ser distintas de empresa para empresa, bem como para cada actividade, ou sector, tendência por vezes atenuada pelos IRCT ${ }^{6}$.

Acresce que, para construir e limitar o conceito de infraç̧ão importa igualmente perceber se tem de existir sempre uma violação do contrato, assim como, saber se o conceito se pode aplicar a comportamentos do trabalhador que não tenham ligação com a prestação de trabalho. Importa também perceber se se pode estender para além da própria prestação do trabalho.

A falta de um conceito, e a fixação dos seus limites deixam em aberto um problema de especial relevo para o trabalhador nesta sede, e que consiste em saber com rigor quais os comportamentos que o empregador lhe pode exigir, sob pena de lhe serem imputadas infracções disciplinares?

Podemos no entanto constatar, que a essência do poder disciplinar assenta na aplicação de sanções ao trabalhador em face do desrespeito por acção ou omissão de deveres contratuais principais ou acessórios que consubstanciam um incumprimento do contrato de trabalho ${ }^{8}$. Impõe-se no entanto, algumas reservas quanto à qualificação das infracções disciplinares. Com efeito, podem existir condutas ilícitas do trabalhador que extravasem em tempo e lugar a execução do próprio contrato de trabalho, mas em relação às quais importe saber se, não obstante o circunstancialismo em que se verificam, podem produzir efeitos disciplinares, por serem abrangidos no conceito de infraç̧ão.

Acrescentamos ainda que, com aplicação para além desta matéria, o Código do Trabalho no artigo $126 .{ }^{\circ} \mathrm{CT}$ estabelece um princípio geral de boa-fé na execução do contrato de trabalho, bem como um dever de mútua colaboração de ambas as partes, o que em simultâneo conforma e limita a actuação do trabalhador em sede de comportamentos aos quais pode ser atribuída relevância disciplinar ${ }^{9}$.

Adquire portanto especial interesse em sede de qualificação dos comportamentos infractores

\footnotetext{
${ }^{5}$ Sobre os requisitos gerais da infracção disciplinar ver NUNO ABRANCHES PINTO, Instituto Disciplinar Laboral, ...cit., p. 70 e sS e PEDRO SOUSA MACED0, Poder Disciplinar Patronal, ....cit., p. 33.

${ }^{6}$ Em relação ao papel das convenções colectivas de trabalho no âmbito do poder disciplinar laboral do empregador, ver ANTÓNIO MENEZES CORDEIRO, Manual de Direito do Trabalho, Almedina, Coimbra, 1991, p. 745.

? PEDRO SOUSA MACEDO, Poder Disciplinar Patronal, ...cit., p. 32, na perspectiva de caracterizar o conceito avança com diversas classificações, atendendo ao tipo de infracção, aos bens ofendidos e à desnecessidade do prejuízo, bem como ao dever ofendido.

${ }^{8} \mathrm{Na}$ perspectiva de delimitar as infracções disciplinares, MARIA DO ROSÁRIO PALMA RAMALHO, Tratado de Direito do Trabalho, Parte II, ...cit., p. 644 , considera que se devem conjugar por um lado, os deveres do trabalhador previstos no artigo $128 .^{\circ} \mathrm{CT}$ e, por outro, as situações que integram a justa causa previstas no $\mathrm{n}^{\circ} 2$ do artigo $351 .{ }^{\circ} \mathrm{CT}$, tarefa ainda assim complexa, atento o conteúdo exemplificativo de ambas as normas. ${ }^{9}$ Sobre a boa-fé na disciplina geral dos contratos, ver JOÃO DE MATOS ANTUNES VARELA, Das Obrigações em Geral, Vol I, 10 a Edição, Almedina, Coimbra, 2000, p. 129 e ss.
} 
do trabalhador, os comportamentos extra-contratuais do trabalhador que possam ser qualificáveis como infracção disciplinar. Trataremos o tema de seguida.

\section{A relevância disciplinar dos comportamentos extra contratuais do trabalhador}

A existência da infracção disciplinar, que, como referimos, em regra se traduz numa violação do contrato e dos deveres do trabalhador, releva especialmente pelas consequências que produz na relação de trabalho. Tal conclusão, é ainda mais notória na apreciação das infracções a que a lei atribui a natureza de justa causa para o despedimento, o que terá de ser apreciado nos termos do n. ${ }^{0} 1$ do artigo $351 .^{\circ} \mathrm{CT}$.

Como já demos nota ao não definir infracção, o legislador deixou ao interprete a resolução de diversas questões, em particular esta que agora tratamos, e que nos leva reflectir até que ponto é que os comportamentos adoptados pelo trabalhador fora do local de trabalho e do tempo de trabalho, podem configurar a existência de uma infracção disciplinar ${ }^{10}$.

Numa abordagem simplista e invocando até o texto da lei, diríamos que o poder disciplinar é inerente ao contrato de trabalho, logo só deve existir disciplina quando o contrato está a ser executado.

0 problema nem sempre é fácil de tratar e levanta desde logo a questão do trabalhador saber onde começa e acaba a sua esfera privada e a sua liberdade face às suas obrigações contratuais laborais.

A protecção da esfera privada do trabalhador está especialmente tratada na lei laboral, por via da consagração dos direitos de personalidade do trabalhador na relação de trabalho, o que se verifica nos artigos $14 .^{\circ}$ e seguintes do $\mathrm{CT}^{11}$.

Sucede frequentemente que a acção disciplinar do empregador colide, com direitos de personalidade do trabalhador, e alguns deles constitucionalmente consagrados, o que também adensa a dificuldade de tratar esta questão.

Em tese, e respeitando determinadas condutas à esfera privada do trabalhador, desde que praticadas fora do tempo e do lugar de trabalho ficariam de fora da alçada disciplinar do empregador. Porém, com frequência encontramos situações em que o comportamento extracontratual do trabalhador influencia e determina, ainda que indirectamente, a sua postura na relação laboral, pelo que somos levados a admitir a possibilidade da sua relevância disciplinar ${ }^{12}$.

Considerando todavia, que a acção disciplinar do empregador possa ultrapassar as fronteiras do contrato de trabalho, impõe-se no entanto, salvaguardar as repercussões de tal entendimento, em particular no que respeita à personalidade e individualidade do trabalhador. Sendo

\footnotetext{
${ }^{10}$ Em particular sobre a relevância destes comportamentos do trabalhador, ver DIOGO LEOTE NOBRE, A relevância dos comportamentos extralaborais em sede de justa causa de despedimento, in Revista da Ordem dos Advogados, ano 68, 2008, p. 923-960. Sobre o interesse e os efeitos que estas condutas extra contratuais podem provocar na esfera jurídica do trabalhador, em especial enquanto justa causa de despedimento, ver GUILHERME MACAHDO DRAY, Justa causa e esfera privada, in Estudos do Instituto de Direito do Trabalho, II, Coimbra 2001, p. 35-96.

${ }^{11}$ Sobre os limites da esfera privada do trabalhador ver ANTÓNIO MENEZES CORDEIRO, 0 respeito pela esfera privada do trabalhador, in I Congresso Nacional de Direito do Trabalho, Almedina, Coimbra, 1998, p. 19-37 e MARIA MALTA FERNANDES, Os limites à subordinação jurídica do trabalhador, Quid luris, Lisboa, 2008, p. 148.

${ }^{12}$ DIOGO LEOTE NOBRE, A relevância dos comportamentos extra-laborais em sede de justa causa de despedimento, ...cit., p. 936 e ss, apresenta algumas categorias de comportamentos extra-laborais do trabalhador que em seu entender podem configurar justa causa de despedimento, a saber: comportamentos que violam o dever de respeito e urbanidade perante a entidade empregadora ou os seus representantes, comportamentos lesivos da imagem, prestígio ou credibilidade da empresa; prática, no âmbito da empresa, de violências físicas ou injúrias sobre colegas de trabalho; comportamentos da vida familiar, afectiva e sexual; factos delituosos cometidos fora da relação laboral; alcoolismo e toxicodependência; doenças infecto-contagiosas (HIV ou SIDA); situações de incompatibilidade pessoal grave com o representante do empregador ou o próprio empregador, entre outras.
} 
necessário conjugar e ponderar diversos aspectos.

Em prol da relevância disciplinar das condutas extra-contratuais do trabalhador notamos especialmente que sendo o contrato de trabalho um contrato intuitus personae, não se desliga da personalidade do trabalhador. 0 trabalhador coloca as suas características pessoais ao serviço do empregador que devem ser atendidas e consideradas pelo empregador. Porém, a dificuldade resulta de não ser possível estabelecer uma barreira relativa ao que respeita directamente à execução do contrato, e ao que está para além dela.

Acresce que o próprio princípio da boa-fé $\left(126 .{ }^{\circ} \mathrm{n} .{ }^{0} 1 \mathrm{CT}\right.$ ) reportado à execução do contrato de trabalho obriga a que o trabalhador adeqúe as suas condutas privadas na execução do seu contrato ${ }^{13}$.

Também o princípio da mútua colaboração previsto no artigo $126 .{ }^{\circ} \mathrm{n} .{ }^{\circ} 2 \mathrm{CT}$, cuja previsão também condiciona [as partes] mas especialmente o trabalhador a comportar-se na sua vida pessoal e social de maneira a não prejudicar o empregador.

Ou seja, em concreto, fruto da inter-ligação e da complementaridade da vida profissional e da vida privada do trabalhador, admitimos que este possa ver limitada a sua esfera privada de acção, mas sem lhe "laboralizar" completamente a sua vida privada ${ }^{14}$.

A doutrina e a jurisprudência tem nesta sede buscado critérios que procurem simultaneamente justificar e limitar a relevância disciplinar das condutas extra contratuais do trabalhador ${ }^{15}$.

Especialmente pelos tribunais tem sido proposto que a conduta privada do trabalhador só possa relevar em termos disciplinares, se existir um nexo de causalidade entre os comportamentos do trabalhador e os seus efeitos sobre o contrato de trabalho ${ }^{16}$. Entendimento com 0 qual concordamos.

\section{As sanções disciplinares: aspectos gerais}

0 exercício do poder disciplinar pelo empregador materializa-se na possibilidade que o empregador dispõe de aplicar ao trabalhador as sanções previstas no n. ${ }^{0} 1$ do artigo $328 .{ }^{\circ} \mathrm{CT}^{17}$. Tal como sucede com os demais institutos, designadamente o de infracção disciplinar. Também em matéria de sanções disciplinares, o legislador não apresenta qualquer definição $0^{18}$.

Em matéria de sanções disciplinares vigora o princípio da tipicidade, embora esta tipicidade não seja tão apertada como noutros ramos do direito, como por exemplo, no direito penal ${ }^{19}$.

\footnotetext{
${ }^{13}$ JÚLIO MANUEL VIEIRA GOMES, Direito do Trabalho - Relações Individuais de Trabalho, Volume I ...cit., p. 884, apresenta diversos exemplos em que a actividade concretamente exercida pelo trabalhador pode condicionar a sua postura pessoal, sob pena de, actuação diferente configurar uma infracção disciplinar. Assim, considera por exemplo, que cantarolar ou assobiar poderá configurar uma infracção pelo incómodo causado aos colegas, e pela perturbação na empresa. Também pode configurar uma infracção disciplinar a expressão de felicidade na cara de um funcionário de uma funerária.

${ }^{14}$ A expressão é de DIOGO LEOTE NOBRE, A relevância dos comportamentos extra-laborais em sede de justa causa de despedimento, ...cit., p. 957.

${ }^{15}$ Em especial no que concerne à relevância destes comportamentos para efeitos de justa causa de despedimento MARIA DO ROSÁRIO PALMA RAMALHO, Tratado de Direito do Trabalho, Parte II, ...cit., p. 824.

${ }^{16}$ A título de exemplo, vejam-se as seguintes decisões dos tribunais Ac. STJ de 24 de Abril de 5.069,84cm BMJ 456, p. 276 e Ac, RE de 12 de Junho de 1991, in CJ, XVI, TIII, p. 315. No primeiro aresto considerou-se que tem relevância disciplinar o comportamento do bancário (que fora da relação laboral) dá ordem de aquisição de títulos em bolsa ao banco sem ter saldo na conta que detém no seu empregador para as pagar. No segundo considerou-se que tem relevo disciplinar a actuação de um sujeito que exerce as funções de guarda nocturno num palácio, e que funciona como receptador de objectos furtados. Igualmente o Ac. STJ de 15 de Janeiro de 2008, in CJ (STJ), 33, 1, 2008, p. 268-270, considerou ser justa causa a venda de droga por um trabalhador aos seus colegas de trabalho, ainda que o fizesse fora do local de trabalho. ${ }^{17}$ De notar que, com a entrada em vigor do Código do Trabalho de 2003 observou-se uma tendência geral no sentido do agravamento dos limites das sanções disciplinares, em especial no que respeita à sanção pecuniária e à suspensão com perda de retribuição e antiguidade. ${ }^{18}$ Em especial sobre o tema ver ANTÓNIO MONTEIRO FERNANDES, As sanções disciplinares e a sua graduação, in Estudos Sociais e Corporativos, n. ${ }^{\circ} 36,1970$, p.23-54
} 
0 princípio da tipicidade visa especialmente impedir o empregador da criação de novas sanções para além das contempladas na lei. Em particular impede-se o empregador de criar novas sanções através de regulamentos internos, pela "facilidade" que dispõe em elaborar estes instrumentos. Pela consagração da tipicidade garante-se nomeadamente aos trabalhadores os seus direitos, em especial, os previstos no artigo $129 .{ }^{\circ} \mathrm{CT}$, assim como se lhes assegura a sua dignidade enquanto sujeitos titulares desses direitos ${ }^{20}$.

No entanto, a temperar esta tipicidade do elenco das sanções, o Código do Trabalho [328. ${ }^{\circ}$ n. ${ }^{\circ}$ 2) admite a existência e aplicação de outras sanções previstas em Instrumento de Regulamentação Colectiva do Trabalho, desde que não prejudiquem os direitos e garantias do trabalhador $^{21}$, e que em concreto possam aplicar-se àquela relação laboral ${ }^{22}$.

Em matéria de sanções disciplinares há dois aspectos do seu regime que importa salientar. Por um lado, a perspectiva conservadora do vínculo laboral ${ }^{23}$, e por outro lado, a sua proximidade relativamente às sanções penais, isto apesar de as primeiras se esgotarem nos interesses privados que subjazem ao contrato de trabalho e as segundas visarem o interesse público.

Com efeito, do elenco das sanções previstas, todas apresentam uma perspectiva conservatória da relação de trabalho, excepção feita à mais grave delas. 0 despedimento, trata-se de uma sanção expulsiva, em que a punição é precisamente a cessação do contrato de trabalho ${ }^{24}$.

Referimos também que encontramos na doutrina diferentes classificações das sanções disciplinares, consoante a sua natureza e os efeitos que produzem.

A classificação tradicional das sanções disciplinares distingue entre sanções conservatórias, e sanções não conservatórias - o despedimento sem indemnização ou compensação ${ }^{25}$.

Existem também classificações que distinguem entre sanções morais ou não patrimoniais - cujos efeitos incidem na pessoa do trabalhador, e de que são exemplos a repreensão e a repreensão registada e sanções pecuniárias cujos efeitos se verificam no património do trabalhador, e de que são exemplo a sanção pecuniária ${ }^{26}$.

Encontramos ainda aquelas cujos efeitos se verificam ao nível da prestação de actividade, restringindo-a, e de que são exemplos a suspensão com perda de retribuição e antiguidade e a perda de dias de férias.

No que concerne à natureza das sanções disciplinares, estas apresentam como já referimos, um carácter marcadamente punitivo, afastando-se por essa razão, de outros institutos, como

\footnotetext{
${ }^{19}$ JÚLIO MANUEL VIEIRA GOMES, Direito do Trabalho - Relações Individuais de Trabalho, Volume I ...cit., p. 894 refere aliás, a existência de um numerus apertus e não de um elenco taxativo no elenco de sanções.

${ }^{20}$ Neste sentido, por exemplo, a despromoção é proibida porque viola o direito do trabalhador de não ser colocado em categoria inferior nos termos previstos na alínea d) do n. ${ }^{\circ} 1$ do artigo $129 .{ }^{\circ} \mathrm{CT}$, o mesmo se diga em relação à transferência do trabalhador para outro local de trabaIho, cuja medida aplicada como sanção violaria a garantia da inamovibilidade, cfr. alínea f) do n. ${ }^{\circ} 1$ do artigo $129 .{ }^{\circ} \mathrm{CT}$.

${ }^{21}$ Nos termos do previsto no artigo $3 .^{\circ} \mathrm{n} .{ }^{\circ} 5 \mathrm{CT}$, existe a possibilidade de esta norma poder ser afastada por IRCT, mas já não por contrato de trabalho.

${ }^{22}$ Como sabemos a aplicação de uma convenção colectiva de trabalho só pode verificar-se numa das seguintes situações: se o trabalhador for filiado na associação sindical que a outorgou, ou que a ela venha aderir e simultaneamente preste actividade num empregador que a ela tenha aderido; se existir uma portaria de extensão que determine a aplicação da CCT às partes, e ainda quando o trabalhador não sendo filiado aderir voluntariamente a uma convenção colectiva de trabalho que seja aplicada na sua empresa, conforme previsto respectivamente, nos artigos $496 .^{\circ}, 514 .^{\circ} \mathrm{e} 497 .{ }^{\circ} \mathrm{CT}$.

${ }^{23}$ A este propósito JULIO MANUEL VIEIRA GOMES, Direito do Trabalho - Relações Individuais de Trabalho, Volume I ...cit., p. 885 refere que o que o carácter conservatório das sanções é o que há de mais específico no poder disciplinar do empregador.

${ }^{24}$ PEDRO SOUSA MACEDO, Poder Disciplinar Patronal, ...cit., p. 25 considera que a sanção não traduz apenas a punição, mas também a modificação negativa das condições de prestação de trabalho que tenham por motivo uma actuação do trabalhador que se pretende reprimir. ${ }^{25}$ Sobre o tema ver MARIA DO ROSÁRIO PALMA RAMALHO, Tratado de Direito do Trabalho, Parte II, ...cit., p. 634, JÚLIO MANUEL VIEIRA GOMES, Direito do Trabalho - Relações Individuais de Trabalho, Volume I ...cit., p.886 e NUNO ABRANCHES PINTO, Instituto Disciplinar Laboral ...cit., p. 90.

${ }^{26}$ Cfr. NUNO ABRANCHES PINTO, Instituto Disciplinar Laboral ...cit., p. 91.
} 
por exemplo, o da responsabilidade civil, que aparece como o meio de reacção comum às situações de incumprimento contratual fora do contrato de trabalho ${ }^{27}$.

Há porém várias diferenças entre os institutos disciplinar e da responsabilidade civil. Em especial, porque pela aplicação da sanção disciplinar não se procura ressarcir qualquer dano ou prejuízo que o trabalhador tenha causado ao empregador, mesmo nos casos em que apresente natureza patrimonial ${ }^{28}$. Acresce que as sanções disciplinares apresentam um cunho eminentemente pessoal, cujos efeitos se projectam especialmente na pessoa do trabalhador, embora cumpram uma função preventiva e repressiva semelhante às sanções penais. Pelos aspectos que indicamos, as sanções disciplinares afastam-se da responsabilidade civil como meio de reacção ao incumprimento contratual laboral, aproximam-se por sua vez das sanções penais, designadamente quanto à sua natureza marcadamente punitiva ${ }^{29}$.

Com efeito, há vários pontos de contacto entre o exercício da acção disciplinar pelo empregador e a aplicação de sanções penais pelo estado ${ }^{30}$.

Feitas estas considerações gerais, analisaremos de seguida o elenco das sanções disciplinares.

\subsection{Os tipos de sanções disciplinares}

Analisaremos agora cada uma das sanções previstas no n. ${ }^{0} 1$ do artigo $328 .{ }^{\circ} \mathrm{CT}$, apontando as especificidades de cada uma e os limites que a própria lei estabelece. Seguiremos a ordem legal, que as gradua da menos grave até à mais grave ${ }^{31}$.

\subsubsection{Repreensão}

A sanção de repreensão é a mais leve das sanções previstas no CT. Esta sanção consiste na chamada de atenção ao trabalhador relativamente a um comportamento por si adoptado e que merece a censura imediata do empregador.

Esta sanção esgota-se na advertência ou admoestação que o empregador dirige verbalmente ao seu trabalhador, no sentido de que futuramente não deverá adoptar o mesmo tipo de comportamento.

Ao trabalhador deve sempre ser dada a possibilidade de ser ouvido, assegurando-lhe assim a sua defesa, em cumprimento do disposto no n. ${ }^{\circ} 6$ do artigo $329 .^{\circ} \mathrm{CT}$, que prevê que a sanção disciplinar não pode ser aplicada sem audiência prévia do trabalhador.

Sendo a aplicação desta sanção marcada pela oralidade, os momentos de aplicação da sanção pelo empregador e da defesa do trabalhador podem confundir-se ${ }^{32}$.

Existe no entanto a dificuldade de compatibilizar a sua aplicação com a obrigação de registo

\footnotetext{
${ }^{27}$ Relativamente à possibilidade de aplicar conjuntamente os dois institutos admite-se a sua utilização cumulativa visto que perseguem finalidades distintas, neste sentido JÚLIO MANUEL VIEIRA GOMES, Direito do Trabalho - Relações Individuais de Trabalho, Volume I ...cit. p. 888. ${ }^{28}$ Nesta perspectiva com a qual concordamos ver JÚLIO MANUEL VIERA GOMES, Direito do Trabalho - Relações Individuais de Trabalho, Volume I...cit., p. 887 e MARIA DO ROSÁRIO PALMA RAMALHO, Tratado de Direito do Trabalho, Parte II,..cit., p. 658. Em sentido oposto, admitindo que as sanções disciplinares são semelhantes à responsabilidade civil, PEDRO ROMANO MARTINEZ, Direito do Trabalho, ...cit., p. 597.

${ }^{29}$ Neste sentido ANTÓNIO JORGE DA MOTTA VEIGA, Lições de Direito do Trabalho ...cit., p. 385 e JÚLIO MANUEL VIEIRA GOMES, Direito do Trabalho - Relações Individuais de Trabalho, Volume I...cit., p. 887 e 888.

${ }^{30}$ JÚLIO MANUEL VIEIRA GOMES, Direito do Trabalho - Relações Individuais de Trabalho, Volume I ...cit., p. 887, aponta os seguintes aspectos, ambas visam pessoas singulares, pressupõem a imputabilidade e a culpa do infractor, culpa essa que não pode presumir-se.

${ }^{31}$ Em relação à legislação em vigor antes do Código do Trabalho, é possível apontar as seguintes diferenças: a multa passa a designar-se sanção pecuniária, prevê-se uma nova sanção de perda de dias de férias, a que acresce uma alteração de terminologia relativamente à sanção mais grave que passa a designar-se despedimento sem indemnização ou compensação.

${ }^{32}$ No que concerne às dificuldades de aplicação desta sanção, MARIA DO ROSÁRIO PALMA RAMALHO, Tratado de Direito do Trabalho, Parte II, ...cit., p. 650, alerta para a dificuldade de compatibilizar esta sanção com a aplicação das regras do processo disciplinar. Já ABÍLIO NETO, Processo Disciplinar e Despedimentos. Jurisprudência e Doutrina, Ediforum, 2004, p. 13, defende a extinção desta sanção enquanto sanção autónoma.
} 
das sanções disciplinares a cargo do empregador. Sendo esta uma sanção que se aplica verbalmente, escapa ao registo a que as demais sanções disciplinares estão sujeitas por força da disciplina do artigo $332 .{ }^{\circ} \mathrm{CT}$, advindo também desta característica a sua natureza de sanção mais leve ou menos gravosa para o trabalhador $^{33}$.

É aliás esta a característica do seu regime que a diferencia da repreensão registada ${ }^{34}$.

\subsubsection{Repreensão registada}

Do ponto de vista do conteúdo, esta sanção é equivalente à repreensão não registada que analisamos, mas difere daquela relativamente às consequências ou efeitos. Tratando-se igualmente de uma advertência ou censura do empregador relativamente à acção do trabaIhador, à qual o trabalhador há-de poder defender-se, a sua aplicação ficará registada no registo de sanções disciplinares. A importância do registo desta sanção releva especialmente se houver necessidade de aplicar ao trabalhador nova sanção disciplinar.

\subsubsection{Sanção pecuniária}

A aplicação desta sanção consiste no não pagamento ao trabalhador da totalidade da sua retribuição. Antes do Código do Trabalho esta sanção tomava a designação de multa ${ }^{35}$.

Porém apesar de a sanção consistir no não pagamento ao trabalhador de parte da sua retribuição, esse valor não reverte para o empregador, devendo nos termos do disposto no n. ${ }^{0} 3$ do artigo $330 .{ }^{\circ} \mathrm{CT}$ ser entregue por aquele ao serviço responsável pela gestão financeira do orçamento da segurança social ${ }^{36}$.

Compreende-se a preocupação do legislador quanto ao destino da sanção, pois poderia ser especialmente tentador para o empregador a aplicação repetida desta sanção ao trabalhador. Aliás de outra forma, para além do efeito sancionatório que produz no património do trabalhador, resultaria também num enriquecimento do empregador porque recebeu o trabalho mas não o pagaria ao trabalhador.

A aplicação desta sanção, não tem carácter indemnizatório, pelo que, não pode ser uma forma de o empregador se ressarcir de quaisquer danos que o trabalhador eventualmente tenha provocado.

Constata-se que o legislador procurou também limitar a aplicação desta sanção quando na al. a) do n. ${ }^{0} 3$ do artigo $328 .^{\circ} \mathrm{CT}$ fixou os seus limites máximos, designadamente se se tratar de infracções praticadas no mesmo dia, a sanção pecuniária não pode exceder um terço da retribuição diária do trabalhador, e em cada ano civil não pode ultrapassar a retribuição correspondente a 30 dias $^{37}$.

\footnotetext{
${ }^{33}$ Neste sentido, DIOGO VAZ MARECOS, Código do Trabalho Anotado. Lei n. ${ }^{07} / 2009$ de 12 de Fevereiro, Wolters Kluwer Coimbra Editora, Coimbra, 2010, p. 781.

${ }^{34}$ Diferentemente NUNO ABRANCHES PINTO, Instituto Disciplinar Laboral, ...cit., p.92 considera que esta sanção deve ser aplicada por escrito. ANA LAMBELHO E LUISA ANDIAS GONÇALVES, 0 Poder Disciplinar e a Justa Causa de Despedimento, Quid Juris Editora, Lisboa, 2012, p. 15 admitem que nada impede que esta repreensão possa assumir a forma escrita, e que o documento do qual conste a repreensão possa ser arquivado, sem que a sanção seja registada no processo do trabalhador. Consideram ainda que esta sanção pode ser aplicada por recurso às novas tecnologias, através da utilização do messenger e do e-mail.

${ }^{35}$ A propósito da alteração da designação, MARIA DO ROSÁRIO PALMA RAMALHO, Tratado de Direito do Trabalho, Parte II, ...cit., p. 649 não concorda que se tenha alterado o nome da sanção invocando especialmente o argumento que há outras sanções com consequências pecuniárias. ${ }^{36}$ Cumprindo-se assim, o princípio geral previsto no $n .{ }^{\circ} 1$ do artigo $279 .{ }^{\circ} \mathrm{CT}$ que impede o empregador de na pendência do contrato de trabalho fazer qualquer compensação ou desconto da retribuição do trabalhador. Este princípio cede no entanto, no caso da aplicação desta sanção, por força da excepção prevista na al. c) do n. ${ }^{2} 2$ do mesmo artigo.

${ }^{37}$ Com a entrada em vigor do Código do Trabalho o limite diário máximo da sanção pecuniária passou de 1/4 para 1/3, ao passo que o limite máximo em cada ano civil passou de 10 para 30 dias.
} 
Desta forma procura-se nomeadamente evitar que o não pagamento da retribuição ao trabaIhador ponha em perigo a sua subsistência e a da sua família, problema especialmente premente quando o trabalhador aufira uma retribuição de valor igual à retribuição mínima mensal garantida.

A previsão desta sanção no ordenamento jurídico laboral português não é isenta de dificuldades, e aliás é proibida noutros ordenamentos como o espanhol e o francês ${ }^{38}$.

\subsubsection{Perda de dias de férias}

A perda de dias de férias é a mais nova das sanções disciplinares previstas no artigo $328 .{ }^{\circ}$ n. ${ }^{0} 1$ d) do Código do Trabalho ${ }^{39}$. Esta sanção foi introduzida como já referimos no elenco de sanções com o CT em $2003^{40}$. Quando o empregador decide pela aplicação desta sanção são retirados ao trabalhador determinados dias de gozo de férias.

A aplicação desta sanção está limitada. No artigo $328 .^{\circ}$ n. ${ }^{\circ} 3$ b) CT o legislador previu que não se pode pôr em causa o gozo de 20 dias úteis de férias pelo trabalhador. Desta forma procura garantir-se a efectivação do princípio constitucional que consagra ao trabalhador o direito ao repouso, assente no direito de gozar em cada ano um período de férias pagas, conforme previsto no artigo $59 .{ }^{\circ}$ n. ${ }^{0} 1 \mathrm{~d}$ ) da CRP.

Para garantir a aplicação do aludido princípio constitucional a lei impede o agravamento desta sanção conforme se colhe do n. ${ }^{\circ} 4$ do artigo $328 .{ }^{\circ} \mathrm{CT}$.

0 tratamento que o legislador conferiu a esta sanção é todavia demasiado escasso, pois apenas fixa o limite que referimos, deixando em aberto diversas questões. A sua utilização não é consensual.

Um dos aspectos que a lei não trata é o de saber se a aplicação desta sanção importa também a perda do correspondente subsídio de férias ${ }^{41}$. Sobre o tema que a doutrina tem discutido há autores que defendem que a sanção compreende apenas a perda de dias de férias. Este é o entendimento maioritário, com o qual concordamos. Embora para outros autores, a sanção compreenda também o não pagamento do respectivo subsídio de férias ${ }^{42}$.

Outra questão que a lei não resolve é a de saber se a perda de dias de férias pode ser aplicada a um trabalhador que em concreto, disponha de um período de férias inferior aos vinte dias úteis que a lei refere, o que pode acontecer nomeadamente no ano da contratação do trabaIhador, ou quando o trabalhador tenha renunciado às suas férias. Nestas situações, a doutrina tem considerado que não é possível aplicar a perda de dias de férias ${ }^{43}$.

Existe ainda um outro problema que se pode vir a suscitar com a aplicação desta san-

\footnotetext{
${ }^{38}$ Como refere NUNO ABRANCHES PINTO, Instituto Disciplinar Laboral ...cit., p. 94.

${ }^{39}$ De notar que a Lei $23 / 2012$ de 25 de Junho acabou com a majoração dos dias de férias, pelo que fixou o número de dias de férias para a generalidade dos trabalhadores em 22 dias úteis (artigo $238 .{ }^{\circ} \mathrm{n} .{ }^{\circ} 1 \mathrm{CT}$ ).

${ }^{40}$ A propósito da sua inserção no elenco das sanções, MARIA DO ROSÁRIO PALMA RAMALHO, Tratado de Direito do Trabalho, Parte II, ...cit., p. 648 , considera que a sua previsão no texto da lei não é feliz, quer por razões jurídicas, quer pelas dificuldades práticas que a sua aplicação pode suscitar.

${ }^{41}$ JÚLIO MANUEL VIEIRA GOMES, Direito do Trabalho - Relações Individuais de Trabalho, Volume I ...cit., p. 894, considera que a previsão desta sanção é uma inovação de bondade duvidosa, já que a perda de dias de férias, acompanhada da perda do proporcional do subsídio de férias, acaba por lesar simultaneamente os bens patrimoniais e pessoais do trabalhador.

${ }^{42}$ Em defesa da primeira tese MARIA DO ROSÁRIO PALMA RAMALHO, Tratado de Direito do Trabalho, Parte II, ...cit., p. 649, JÚLIO MANUEL VIEIRA GOMES, Direito do Trabalho - Relações Individuais de Trabalho, Volume I ...cit., p. 894, e, MARIA ADELAIDE DOMINGOS, Poder e Procedimento Disciplinar no Código do Trabalho, ...cit., p. 481. Genericamente consideram que tal prática consistiria noutra sanção. Em sentido oposto NUNO ABRANCHES PINTO, Instituto Disciplinar Laboral ...cit., p. 96.

${ }^{43}$ Neste sentido, MARIA ADELAIDE DOMINGOS, Poder e Procedimento Disciplinar no Código do Trabalho, ...cit., p.480 e MARIA DO ROSÁRIO PALMA RAMALHO, Tratado de Direito do Trabalho, Parte Il, ...cit., p. 719.
} 
çã $0^{44}$. 0 assunto prende-se com a fixação pela lei de um prazo máximo de três meses para a aplicação das sanções $\left(330 .^{\circ}\right.$ n. ${ }^{0} 2 \mathrm{CT}$ ), sob pena de caducidade da sanção. Num caso concreto pode não ser possível cumprir a sanção, se o trabalhador já tiver gozado as suas férias. $\mathrm{Na}$ verdade, e em relação a esta questão, parece-nos que se o empregador não conseguir aplicar a sanção dentro do prazo supra referido, deve escolher no leque de sanções outra que se mostre adequada.

\subsubsection{Suspensão do trabalho com perda de retribuição e de antiguidade}

A suspensão do trabalho com perda de retribuição e de antiguidade é a sanção mais grave do elenco das sanções conservatórias. Na gradação de sanções, acima dela existe apenas o despedimento.

Quando o empregador decide pela escolha desta sanção o trabalhador não presta trabalho, não recebe pelo tempo em que esteve suspenso, assim como, esse tempo não é contabilizado para efeitos de antiguidade, e dos direitos dela decorrentes.

Trata-se de uma sanção destinada a punir infracções disciplinares graves, e por isso produz efeitos relevantes, quer quanto à pessoa do trabalhador, quer quanto ao seu património.

Com efeito, o não pagamento da retribuição redunda num prejuízo que podemos dizer directo, mas também a perda dos direitos decorrentes da antiguidade poderá significar um prejuízo económico com repercussões nos direitos do trabalhador.

Também esta sanção, aparece sujeita a limites máximos previstos no artigo $328 .^{\circ} \mathrm{n} .{ }^{\circ} 2$ al. c), não podendo, por conseguinte, exceder 30 dias por cada infracção, nem em cada ano civil mais de 90 dias $^{45}$.

Durante o período de aplicação da medida de suspensão e não obstante não existir pagamento de retribuição mantém-se as obrigações contributivas das partes ${ }^{46}$.

\subsubsection{Despedimento sem indemnização ou compensação}

0 despedimento sem direito a qualquer indemnização ou compensação é a mais grave das sanções disciplinares ${ }^{47}$. Trata-se da única sanção não conservatória, e de resto, a mais grave de todas as que o empregador pode aplicar ao trabalhador.

A aplicação desta sanção, na medida em que faz cessar o contrato de trabalho, pode em certa medida conflituar com o direito à segurança no emprego, e o direito à retribuição. São essas as razões que levaram o legislador a limitar especialmente a sua aplicação. Assim, e apenas quando se verificarem os requisitos apertados previstos na lei, designadamente os que integram o conceito de justa causa, o empregador tem a faculdade de fazer cessar o contrato de trabalho. São estas as situações em que a manutenção do contrato se encontra irremediavelmente comprometida. Sobre o despedimento disciplinar trataremos mais à frente neste trabalho.

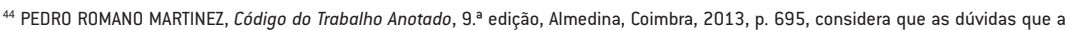
aplicação prática desta sanção levanta, não assume contornos de relevo, visto que os empregadores recorrem quase exclusivamente a três tipos de sanções disciplinares: a repreensão, a suspensão de trabalho com perda de retribuição e antiguidade e o despedimento.

${ }^{45}$ Antes da vigência do Código do Trabalho, na LCT, o limite máximo por cada infracção era de 12 dias, ao passo que em cada ano civil o limite era de 30 dias.

${ }^{46}$ Conforme o disposto no artigo $46{ }^{\circ}, \mathrm{n} .{ }^{\circ} 2$ al. u) do Código dos Regimes Contributivos do Sistema Previdencial de Segurança Social, aprovado pela Lei 110/2009 de 14 de Setembro, o que, em concreto, pode traduzir uma perda para o empregador, que não recebe o trabalho do trabaIhador mas tem de manter o pagamento das contribuições à segurança social.

${ }^{47}$ Importa referir que na actual formulação legal se suprimiu a referência a natureza imediata do despedimento, por se opor à natureza motivada e procedimentalizada do despedimento.
} 


\subsection{Princípios orientadores para determinação das sanções disciplinares}

Um dos aspectos mais delicados da utilização do poder punitivo do empregador consiste na escolha da sanção a aplicar em face da infracção disciplinar. 0 poder disciplinar cujos contornos de discricionariedade são evidentes, está sujeito a diversos limites e, deve ser utilizado pelo empregador em conformidade com os pressupostos da figura do abuso de direito prevista no artigo $334 .^{\circ} \mathrm{CC}^{48}$.

Relativamente à determinação da sanção pelo empregador, a nossa lei estabelece diversos princípios que a devem orientar e cujo objectivo é ao mesmo tempo limitar o exercício do poder de que o empregador é titular.

Com a sua previsão pretende-se confinar as hipóteses de uso abusivo deste poder pelo empregador, e diminuir a discricionariedade na sua utilização, inviabilizando nomeadamente a aplicação de sanções dissimuladas ao trabalhador. Situação a que alguma doutrina refere como a aplicação de sanções ocultas ao trabalhador, e que muitas vezes configuram a aplicação de sanções abusivas ${ }^{49}$.

Na senda de garantir a escolha equilibrada e a aplicação justa da sanção, a lei fornece ao empregador dois critérios gerais que o mesmo deve considerar aquando da escolha: 0 da proporcionalidade da sanção à gravidade da infracção e à culpa do infractor e o da proibição da aplicação de mais do que uma sanção pela mesma infracção.

A norma em referência é uma norma aberta que se limita a fornecer ao empregador os critérios gerais para a escolha da sanção adequada ao comportamento do trabalhador, e cuja aplicação pode também variar de empregador para empregador.

0 facto de a lei não definir o conceito de infracção, nem estabelecer os termos em que as diversas sanções deverão ser aplicadas dificulta de sobremaneira a actuação do empregador ${ }^{50}$. A técnica legislativa utilizada sujeita especialmente o empregador à sindicância da aplicação de sanções levada a cabo pelo trabalhador. Seria certamente mais fácil para o empregador se o legislador tivesse optado por outra fórmula legal, prevendo um elenco de infracções às quais corresponderia determinada sanção $0^{51}$.

Não foi este o caminho seguido, visto que, e se por um lado, seria impossível tipificar todas as infracções cometidas pelo trabalhador, por outro, fazer corresponder sempre a mesma sanção ao comportamento do trabalhador, sem analisar a culpa e a gravidade da acção do sujeito no caso concreto, poderia revelar-se injusto e desadequado ${ }^{52}$.

A questão prática que se coloca frequentemente ao empregador é a de saber como decidir a escolha da sanção a aplicar num caso concreto com respeito pelos princípios enunciados ${ }^{53}$.

\subsubsection{0 princípio da proporcionalidade}

0 princípio da proporcionalidade consagrado no artigo $330 .^{\circ} \mathrm{n} .{ }^{0} 11 .^{a}$ parte $\mathrm{CT}$, impõe que o

\footnotetext{
${ }^{48}$ Considera-se ilegítimo o exercício de um direito quando o titular exceda manifestamente os limites impostos pela boa fé, pelos bons costumes ou pelo fim social ou económico desse direito.

${ }^{49}$ Sobre este tipo de sanções ver MARIA DO ROSÁRIO PALMA RAMALHO, Os Limites do Poder Disciplinar Laboral, ...cit., p. 188 e PEDRO SOUSA MACEDO, Poder Disciplinar Patronal ...cit., p. 40.

${ }^{50}$ No âmbito do direito penal, diferentemente do que sucede no instituto disciplinar laboral, e visto que a condução do processo está sujeita a critérios de legalidade estrita, é possível encontrar-se a previsão exacta dos comportamentos que conduzirão à aplicação das sanções.

${ }^{51}$ Como sucede designadamente com o Estatuto Disciplinar da Função Pública.

${ }^{52}$ A este propósito NUNO ABRANCHES PINTO, Instituto Disciplinar Laboral ...cit., p. 107 considera que foi a falta da definição geral de infracção e de infracções em concreto que impediu o legislador de estabelecer uma correspondência entre infracções e sanções.

${ }^{53}$ Importa todavia referir que para o empregador não surge responsabilidade se iniciar o processo disciplinar e se, no seu decurso apurar que o trabalhador não cometeu qualquer infracção. Neste sentido PEDRO ROMANO MARTINEZ, Direito do Trabalho ...cit., p. 599.
} 
empregador escolha a sanção adequada à gravidade da infracção e à culpa do trabalhador infractor. Por aplicação do aludido princípio deve a sanção ser menos grave quanto mais reduzidas forem a gravidade e a culpa do infractor, e ao contrário deve a sanção ser mais grave quanto mais o forem a gravidade e a culpa ${ }^{54}$.

A proporcionalidade na aplicação de sanções é também um corolário do princípio da boa-fé que visa impedir a escolha e a aplicação de sanções desajustadas aos trabalhadores.

Com efeito, e apesar de a regra ser perfeitamente perceptível a aplicação casuística do princípio nela contido levanta diversas dificuldades.

Contudo, se os critérios de valoração utilizados pelo empregador, não forem correctos e adequados o trabalhador, pode sindicá-los judicialmente ${ }^{55}$.

A aferição da proporcionalidade na escolha da sanção faz-se, desde logo, por comparação entre a escolha de uma sanção conservatória ou não conservatória. Pois, o despedimento, sendo a sanção não conservatória prevista na lei, só há-de aplicar-se se as punições menos gravosas não se mostrarem justas e adequadas.

Impõe-se todavia notar que para aplicar o princípio da proporcionalidade, o empregador terá de formular juízos de valor em relação à apreciação da gravidade do comportamento e à culpa do infractor ${ }^{56}$. A consideração destes juízos de valor, reflecte vários aspectos de ordem subjectiva e social, podendo também ser distintos de empregador para empregador.

Em relação ao comportamento do trabalhador, o empregador terá de aferir essencialmente dois aspectos, por um lado, a atitude do trabalhador e as suas consequências ao nível da relação jurídico laboral, podendo caber aqui a valoração do dano produzido para o empregador ${ }^{57}$, e por outro, a conduta anterior e posterior à infracção (arrependimento demonstrado), cabendo aqui especial valoração dos antecedentes disciplinares do trabalhador.

\subsubsection{O Princípio da unicidade}

0 outro princípio que condiciona a acção do empregador em matéria de escolha da sanção a aplicar ao trabalhador é o que se encontra enunciado na $2{ }^{a}$ parte do n. ${ }^{0} 1$ do artigo $330 .{ }^{\circ} \mathrm{CT}$, e que prevê que o empregador não possa aplicar mais do que uma sanção disciplinar pela mesma infracção.

Com a previsão deste princípio da unidade da sanção, reflexo ele próprio do princípio da proporcionalidade, o legislador procurou proteger o trabalhador. Ao impedir a aplicação de várias sanções pela mesma infracção evita que se desvirtue o princípio a que alude na primeira parte da norma, e mais do que isso, impede os resultados desajustados a que eventualmente

\footnotetext{
${ }^{54}$ PEDRO SOUSA MACEDO, Poder Disciplinar Patronal, ...cit., p. 56 considera que a aplicação deste princípio pelo empregador implica uma dupla apreciação, por um lado, a determinação da gravidade da falta, e por outro a efectivação da graduação das sanções.

${ }^{55}$ Como aliás nota PEDRO SOUSA MACEDO, Poder Disciplinar Patronal, ...cit., p. 23, o poder disciplinar, como todo o poder é susceptível de desvio que pode manifestar-se precisamente pela desproporção entre a gravidade da infracção e a sanção aplicada.

${ }^{56}$ Tal como considerou o Ac. STJ de 8 de Janeiro de 2013, processo $n .{ }^{\circ} 447 / 10.4 T T V N F . P 1 . S 1$, disponível em www.dgsi.pt, que relativamente ao trabalhador bancário que solicitava empréstimos a clientes da sua empregadora se achava violado o princípio da confiança, pelo que a sanção do despedimento se mostra adequada ao principio da proporcionalidade " 0 princípio da proporcionalidade, convocado aquando da selecção da sanção disciplinar tida por adequada, orienta e informa o empregador, enquanto decisor, da necessidade de observar, no momento próprio, a regra segundo a qual a sanção por que se opte deve corresponder, em termos de proporcional severidade, à gravidade da conduta infraccional, avaliada em si e nas suas consequências, e ao grau de culpa do infractor, ambas aferíveis pelo padrão convencional do homem médio/ "bonus paterfamilias" e reportadas ao quadro atendível na apreciação da justa causa prefigurado no n. 3 do art. $351 .^{\circ}$ do CT/2009".

${ }^{57}$ Como já mencionamos, a generalidade da doutrina considera que para haver sanção disciplinar não é necessária a existência de um dano. Neste sentido, PEDRO SOUSA MACEDO, Poder Disciplinar Patronal, ...cit., p. 56, JÚLIO MANUEL VIEIRA GOMES, Direito do Trabalho - Relações Individuais de Trabalho, Volume I ...cit., p. 888 e NUNO ABRANCHES PINTO, Instituto Disciplinar Laboral ...cit., p. 108.
} 
conduziria.

De notar que, não obstante o princípio da unicidade da sanção, o comportamento do trabaIhador punido disciplinarmente pode também dar lugar à responsabilidade civil ou mesmo criminal.

A previsão desta norma consagra o designado princípio ne bis in idem, especialmente relevante em sede de aplicação de sanções penais.

A preocupação do legislador é garantir ao trabalhador que pela mesma infracção não lhe será aplicada mais do que uma sanção. Estranhamente não se faz na lei qualquer referência à situação das infracções continuadas, assim como para o caso de existirem várias infracções distintas tratadas no mesmo processo disciplinar. Deixando nestes casos à consideração do intérprete a decisão de saber, se, nessas situações deve aplicar uma ou várias sanções ${ }^{58}$.

\subsubsection{0 princípio da coerência disciplinar}

Impõe-se referir que para além dos princípios enunciados na lei, vem-se discutindo na doutrina e na jurisprudência, no sentido de saber se existe a sujeição a um "princípio de igualdade" na prática disciplinar levada a cabo pelo empregador, também designado de coerência disciplinar da empresa.

A esta questão, a maior parte da doutrina responde negativamente, admitindo por conseguinte que a mesma infracção possa ser diferentemente punida quando praticada por trabalhadores diferentes, nas mesmas circunstâncias, ou quando praticada por trabalhadores possa ser punida em relação a um deles, e já não relativamente ao outro ${ }^{59}$.

Igualmente a jurisprudência, em especial o Supremo Tribunal de Justiça, têm respondido negativamente à questão enunciada. Tem considerado que a prática disciplinar deve encarar-se como um corolário do princípio constitucional da igualdade. Admitindo porém que não existe violação do princípio quando o empregador considerou existir justa causa para despedir um trabalhador e não os outros trabalhadores que intervieram nos mesmos factos ${ }^{60}$. Solução com a qual concordamos e que se adequa à natureza discricionária deste poder disciplinar do empregador.

\subsection{A possibilidade de agravamento das sanções disciplinares}

Apesar da previsão de limites máximos, o legislador admite que as sanções possam ser agravadas, podendo ser esse o mecanismo que, em concreto, permita evitar o despedimento do trabalhador ${ }^{61}$, já que agravando a sanção o empregador não avança para a aplicação da sanção mais grave.

Existem actualmente no Código do Trabalho duas possibilidades distintas de proceder ao agravamento das sanções, em relação a algumas delas, tal pode suceder por via de Instrumento de Regulamentação Colectiva de Trabalho, agravando-se os seus limites máximos. Em relação a todas as sanções, o agravamento pode suceder através da sua divulgação no âmbito da empresa, nos termos previstos nos n. ${ }^{\circ} \mathrm{s} 4$ e 5 do artigo $328 .{ }^{\circ} \mathrm{CT}$.

\footnotetext{
${ }^{58}$ Como especialmente menciona MARIA ADELAIDE DOMINGOS, Poder e Procedimento Disciplinar no Código do Trabalho ...cit., p. 485.

${ }^{59}$ Sobre o tema ver JÚLIO MANUEL VIEIRA GOMES, Direito do Trabalho - Relações Individuais de Trabalho, Volume I ...cit., p.889 e ss.

${ }^{60}$ Sobre o tema vejam-se os Acórdãos STJ de 06 de Dezembro de 2006, processo n. ${ }^{\circ} 006$ B3458, disponível em www.dgsi.pt e de 07 de Fevereiro de 2007, processo n. ${ }^{\circ} 0653320$, disponível www.dgsi.pt

${ }^{61}$ Constata-se, como já apontamos uma tendência do legislador de agravar os limites máximos das sanções, em especial no que toca à sanção pecuniária e à suspensão com perda de retribuição e de antiguidade. A solução legislativa não tem sido isenta de críticas, especialmente no que respeita à suspensão que actualmente pode atingir os 6 meses.
} 
Assim, relativamente à sanção pecuniária e à suspensão do trabalho admite-se o agravamento até ao dobro dos limites máximos previstos, sempre que esteja previsto em IRCT, e apenas neste, e as especiais condições de trabalho o justifiquem, conceito que a lei não explicitou ${ }^{62}$. 0 n. ${ }^{\circ} 5$ do artigo $328 .{ }^{\circ} \mathrm{CT}$ prevê que todas as sanções possam ser agravadas pela divulgação no âmbito da empresa. Contudo não estabelece por que meios a divulgação pode fazer-se, impedindo contudo que seja usada com carácter vexatório ou humilhante para o trabalhador ${ }^{63}$. 0 desrespeito dos limites máximos pelo empregador fá-lo-ão incorrer em responsabilidade contra-ordenacional, prevendo a lei $\left(328 .{ }^{\circ} \mathrm{n} .{ }^{\circ} 6\right]$ ) que se trata de uma contra-ordenação grave. Importa ainda referir que em relação aos diplomas que antecederam o Código de 2003 [em especial a LCT), se verificou um aumento dos limites máximos das sanções, tendência que se manteve em 2009, e que corrobora um dos aspectos da reforma assente numa maior responsabilização das partes quer quanto às obrigações contratuais, quer quanto ao conteúdo dos IRCT ${ }^{64}$.

\subsection{A obrigação de registo das sanções disciplinares}

Nos termos do artigo $332 .{ }^{\circ} \mathrm{CT}$ o empregador deve dispor e manter actualizado para cada trabalhador um registo das sanções disciplinares aplicadas. Este deve ser elaborado de forma a que, permita facilmente a consulta e a verificação por parte das autoridades competentes do cumprimento das normas aplicáveis. A sua falta nos termos previstos faz incorrer o empregador numa contra-ordenação leve, conforme previsto no n. ${ }^{\circ} 2$ do artigo $332 .{ }^{\circ} \mathrm{CT}$.

\subsection{A aplicação de sanções abusivas e os seus efeitos}

A previsão no artigo $331 .^{\circ} \mathrm{CT}$ de uma norma sobre sanções abusivas, tem por base a ideia de que distorcendo os princípios enformadores da aplicação das sanções em geral, e o seu regime em particular, pode o empregador aplicar indevidamente sanções ao trabalhador. Essencialmente a proibição de aplicar sanções abusivas trata-se de um mecanismo de controlo do poder do empregador, e acima de tudo, de protecção do trabalhador.

Neste domínio, o n. ${ }^{0} 1$ do artigo $331 .^{\circ} \mathrm{CT}$ prevê as situações em que a aplicação de sanção disciplinar ao trabalhador é considerada abusiva, ao passo que o $\mathrm{n}^{0}{ }^{0} 2$, estabelece uma presunção que configura a aplicação abusiva de uma sanção ao trabalhador.

Em relação à previsão do $n{ }^{0} 1$ são consideradas abusivas as sanções aplicadas pelo empregador pelo facto de 0 trabalhador ter reclamado legitimamente contra as condições de trabaIho, recusar-se a cumprir ordem a que não deva obediência nos termos da al. e) do n. ${ }^{0} 1$ e n. ${ }^{02}$ do artigo $128 .^{\circ} \mathrm{CT}$, exercer ou candidatar-se ao exercício de funções em estrutura de representação colectiva dos trabalhadores e, em geral, ter exercido, pretender exercer ou invocar os seus direitos e garantias.

Em relação às acções intentadas com algum dos fundamentos previstos no n. ${ }^{0} 1$ vigoram as regras gerais do ónus da prova (artigo $342 .^{\circ} \mathrm{CC}$ ) cabendo por conseguinte ao trabalhador alegar e provar os factos constitutivos do seu direito que evidenciem o uso abusivo da sanção $e$

\footnotetext{
62 MARIA DO ROSÁRIO PALMA RAMALHO, Tratado de Direito do Trabalho, Parte II, ...cit., p. 657, considera que o nosso legislador, relativamente à sanção pecuniária seguiu a tendência inversa à de outros países e à das próprias convenções colectivas, cujo sentido tem sido de eliminar esta sanção pelo facto de a mesma colidir com a função alimentar do salário, e da suficiência salarial mínima.

${ }^{63}$ Neste sentido JÚLIO MANUEL VIEIRA GOMES, Direito do Trabalho - Relações Individuais de Trabalho, Volume I ...cit., p. 895 e ss, considera que também não se poderá divulgar o motivo da aplicação da sanção.

${ }^{64}$ Conforme se colhe do ponto 3.4 da Exposição de Motivos que antecede o Código do Trabalho de 2003.
} 
que se integrem numa das alíneas a) a d) do n. ${ }^{0} 1$ do artigo $331 .{ }^{\circ} \mathrm{CT}$.

No número 2 do mesmo artigo, o legislador estabeleceu uma presunção ilidível, (à luz do regime do artigo $350 .{ }^{\circ}$ do CC) que dispensa o trabalhador de provar o nexo de causalidade entre a sanção aplicada e outras infracções que num determinado espaço temporal, entretanto venham a ser-lhe imputadas.

Nos termos da alínea a) presume-se abusiva a sanção aplicada para punir uma infracção por factos previstos no n. ${ }^{0} 1$ do artigo $331 .^{\circ}$, e que ocorra até seis meses após a ocorrência daqueles factos. No caso da alínea b) quando ocorram até um ano após a reclamação ou outra forma de exercício de direitos relativos a igualdade e não discriminação nos termos previstos na alínea b ${ }^{65}$.

A regra geral em matéria de efeitos de aplicação de sanção abusiva pelo empregador é a da indemnização ao trabalhador nos termos gerais, conforme previsto no n. ${ }^{\circ} 3$ do artigo $331 .^{\circ} \mathrm{CT}$ com as especialidades no caso das sanções previstas nos números 4,5 e 6 do mesmo artigo, em que o legislador quantifica mínimos para as indemnizações.

Assim, se o tribunal considerar que o empregador despediu abusivamente um trabalhador, este tem a possibilidade de optar pela reintegração e uma indemnização fixada pelo tribunal entre 30 e 60 dias de retribuição de base e diuturnidades por cada ano completo ou fracção, mas nunca inferior a 6 meses, nos termos previstos do n. ${ }^{\circ} 3$ do artigo $392 .{ }^{\circ} \mathrm{CT}$. Esta indemnização é ainda mais gravosa do que aquela que o CT prevê no $391 .^{\circ} \mathrm{CT}$ e que o trabalhador pode optar em substituição da reintegração em sede de ilicitude do despedimento.

Se a sanção que o empregador aplicar abusivamente for a sanção pecuniária ou a suspensão do trabalho, a indemnização a pagar ao trabalhador deverá ser fixada em montante não inferior a 10 vezes a importância do valor da sanção ou da retribuição perdida (n. ${ }^{05}$ ).

Já se a sanção abusiva aplicada for motivada pelo facto de o trabalhador exercer ou candidatar-se ao exercício de funções em estrutura de representação colectiva dos trabalhadores, o empregador deve indemnizar o trabalhador com uma indemnização não inferior a 20 vezes 0 valor da sanção pecuniária ou o dobro da retribuição perdida no caso de suspensão.

Se neste quadro a sanção abusiva for o despedimento, o tribunal deve fixar a indemnização ao trabalhador em valor não inferior a 12 meses de retribuição base e diuturnidades (n. ${ }^{\circ} 6$ ).

O legislador não tomou posição, no caso de a sanção abusiva aplicada ser a perda de dias de férias, caso em que parece ser suficiente a devolução ao trabalhador dos dias de férias retirados, e dos valores que eventualmente lhe tenham sido descontados.

\section{Os prazos para o exercício da acção disciplinar pelo empregador}

0 elemento temporal tem especial relevo no exercício do poder disciplinar pelo empregador. Há nesta matéria, a ideia de que a fixação de prazos que condicionem o exercício do poder disciplinar resultam em garantias de certeza e segurança jurídica para ambas as partes, mas especialmente para o trabalhador.

Com efeito, não sendo o exercício do poder disciplinar uma obrigação do empregador, mas antes uma faculdade, a previsão de prazos permitem ao trabalhador avaliar, se determinado

\footnotetext{
${ }^{65} \mathrm{Na}$ revisão de 2009 , a presunção do $\mathrm{n} .{ }^{\circ} 2$ passou a abranger também a alínea c) do n. ${ }^{\circ} 1$ do artigo $331 .^{\circ}$, o que até então não se verificava. Nesse sentido passa a beneficiar da presunção a situação em que se verifique uma punição do trabalhador que exerça ou se candidate ao exercício de funções em estrutura de representação colectiva dos trabalhadores.

Por outro lado, no que concerne à alínea b) estabeleceu-se novamente a regra respeitante aos direitos relativos à igualdade e não discriminação, e que já tinham tido consagração legal no artigo $35 .{ }^{\circ}$ da Lei $35 / 2004$ de 29 de Julho, a lei que regulamentou o CT 2003.
} 
comportamento com relevância disciplinar está ainda em condições [temporais] de ser punido disciplinarmente pelo empregador.

Efectivamente a passagem do tempo, sem que haja qualquer sinal da parte do empregador, quer em regra significar a irrelevância disciplinar dos comportamentos do trabalhador, ou eventualmente uma atitude de perdão do empregador face às infracções disciplinares praticadas.

Com efeito, o decurso do tempo de que o empregador dispõe para exercer o poder disciplinar, sem que o tenha feito, funciona por vezes, como factor libertador do trabalhador, face à "ameaça" da punição resultante do predomínio do empregador.

A previsão de limites temporais para a utilização da acção disciplinar do empregador pode justificar-se, além do mais, por referência ao princípio da imediação. Segundo este princípio quanto mais tempo passar desde a prática da infracção até ao momento em que a sanção se efectivar, menor é a sua eficácia punitiva e o seu efeito útil.

Acresce que também a necessidade de conservação das provas justifica o exercício do poder disciplinar num prazo relativamente curto.

Trataremos agora dos diversos prazos que o exercício da acção disciplinar está sujeita, previstos nos artigos $329 .{ }^{\circ}$ n. ${ }^{0} 1, \mathrm{n} .{ }^{0} 2$ e n. ${ }^{0} 3$ e $330 .{ }^{\circ}$ n. ${ }^{\circ} 2 \mathrm{CT}$, assim como, das consequências que 0 decurso do tempo produz em matéria disciplinar.

Importa além do mais referir que existe ainda um outro prazo em matéria disciplinar (que se relaciona com este) e que obriga o empregador a proferir a decisão de despedimento no prazo de 30 dias após o encerramento das diligências instrutórias ou o recebimento dos pareceres das entidades que representam os trabalhadores, e que está previsto no artigo $357 .{ }^{\circ} \mathrm{n}^{0} 1 \mathrm{CT}$. Sobre este prazo em particular trataremos dele na parte relativa ao procedimento com vista ao despedimento, referindo por agora os restantes prazos, optando por seguir a ordem pela qual aparecem tratados na lei.

\subsection{0 prazo de prescrição da infracção disciplinar}

0 primeiro prazo tratado pelo legislador é o que se encontra previsto no n. ${ }^{0} 1$ do artigo $329 .{ }^{\circ}$ CT. Segundo esta norma, o empregador tem o direito de exercer o poder disciplinar até um ano após a prática da infracção, ou quando o comportamento do trabalhador constituir crime, nos prazos previstos na lei penal ${ }^{66 / 6 ?}$.

Decorre da leitura da norma que o decurso do prazo de prescrição de um ano começa a contar-se a partir da data da infracção, independentemente de o empregador conhecer ou não a

\footnotetext{
${ }^{66} 0$ n. ${ }^{0} 1$ do artigo $118 .^{\circ}$ do Código Penal sob a epígrafe prazo de prescrição, dispõe que: o procedimento criminal extingue-se, por efeito de prescrição, logo que sobre a prática do crime tiverem decorrido os seguintes prazos:

a) 15 anos, quando se tratar de crimes puníveis com pena de prisão cujo limite máximo for superior a 10 anos ou dos crimes previstos nos

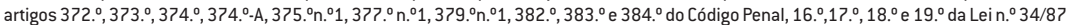
de 16 de Julho, alterada pelas Leis n. ${ }^{\circ}$ s $108 / 2001$ de 28 de Novembro e 30/2008 de 10 de Julho, e $8 .{ }^{\circ}, 9 .^{\circ}, 10 .^{\circ}$ e $11 .^{\circ}$ da Lei n. ${ }^{\circ} 50 / 2007$ de 31 de Agosto, e ainda do crime de fraude na obtenção de subsídio ou subvenção;

b) 10 anos, quando se tratar de crimes puníveis com pena de prisão cujo limite máximo for igual ou superior a cinco anos, mas que não exceda dez anos;

c) 5 anos, quando se tratar de crimes puníveis com pena de prisão cujo limite máximo for igual ou superior a um ano, mas inferior a cinco; d) 2 anos nos casos restantes.

${ }^{67}$ Relativamente à aplicação desta regra da prescrição do direito criminal às infracções disciplinares, PEDRO FURTADO MARTINS, Cessação do Contrato de Trabalho, 3. ${ }^{a}$ edição, Principia Editora Lda, Cascais, 2012, p. 192, considera que o empregador beneficia do prazo previsto no Código Penal para sancionar o trabalhador, isto independentemente de ter apresentado a respectiva queixa, o que em concreto, apenas releva para determinar a extinção da responsabilidade criminal. No mesmo sentido decidiu o Ac. STJ de 13 de Janeiro de 2010 , processo n. ${ }^{\circ}$ 1164/07.8TTPRT.S1, disponível em www.dgsi.pt.
} 
prática da infracção. 0 que significa, portanto que se o empregador conhecer apenas a prática da infracção decorrido que esteja um ano desde o momento da sua ocorrência, o poder disciplinar já não pode ser exercido. Prescreveu o direito do empregador o exercer.

Esta solução garante ao trabalhador que a "expectativa" da punição não se prolongue indeterminadamente no tempo, dando-lhe a tranquilidade necessária para manter uma relação que se caracteriza como duradoura, e que se baseia na confiança.

Adquire especial relevo neste âmbito, por influenciar o início da contagem do prazo referido, a situação das infraç̧ões continuadas, ou seja nos casos em que os comportamentos infractores do trabalhador se mantém no tempo, de forma contínua ou permanente ${ }^{68}$.

Em relação a estas infracções, e não obstante na lei laboral não existir quanto a elas qualquer referência, tanto a doutrina como a jurisprudência têm-Ihe atribuído relevância ${ }^{69}$. Importa salientar que, do ponto de vista conceptual para que exista uma infracção continuada, é determinante que os comportamentos do trabalhador e os bens jurídicos violados sejam os mesmos ou que pelo menos, sejam do mesmo género. Assim, não havendo qualquer ligação entre os comportamentos do trabalhador não se poderá falar de uma infracção continuada, mas antes da existência de diversos comportamentos, que podem constituir outras tantas infracções disciplinares.

Quanto a este tema da relevância disciplinar das infracções continuadas importa, todavia, não perder de vista o fim último da consagração dos prazos que condicionam a acção do empregador, e que funcionam como "presunção" da irrelevância disciplinar directa do comportamento do trabalhador ${ }^{20}$.

Tem-se conjecturado a possibilidade de as infracções prescritas poderem ser consideradas no momento de aplicar outras sanções ao trabalhador.

No que tange ao tema da relevância indirecta das infracções disciplinares prescritas para efeito da determinação da sanção a aplicar noutras situações de infracção, a doutrina tem entendido que as infracções que prescreveram não podem ser consideradas para efeito de punição autónoma, mas podem servir, nomeadamente, para valorar a postura do trabalhador na empresa ${ }^{71}$. No que se refere à qualificação das faltas injustificadas do trabalhador como infracções continuadas tem-se verificado algumas divergências interpretativas.

No caso previsto na alínea g] do n. ${ }^{\circ} 2$ do artigo $351 .^{\circ} \mathrm{CT}$, a principal questão que se coloca tem a ver com a eventual relação com o prazo para iniciar o procedimento disciplinar. Com efeito, o legislador refere que no cômputo dessas faltas são consideradas todas as faltas dadas pelo trabaIhador em cada ano civil, o que lido à letra parece querer dizer que os prazos para o exercício da aç̧ão disciplinar só se iniciariam no início do ano civil seguinte, opinião que não é consensual?2. Importa acentuar que o desrespeito deste prazo pelo empregador torna o despedimento por facto imputável ao trabalhador ilícito, nos termos do artigo $382 .{ }^{\circ}$ n. ${ }^{0} 1$ CT. Cabe ao trabalhador

\footnotetext{
${ }^{68}$ Sobre o conceito, ver MANUEL LOPES MAIA GONÇALVES, Código Penal Anotado, 17. a Edição, Almedina, Coimbra, 2005 , p. $145-153$.

${ }^{69}$ Quanto à doutrina ver entre outros, PEDRO SOUSA MACEDO, Poder Disciplinar Patronal, ...cit., p.117, INÊS ALBUQUERQUE E CASTRO, A Repercussão do Tempo no Procedimento Disciplinar. Da Prescrição, Caducidade, Duração da Instrução e Inobservância do Prazo de Decisão, in, Estudos do Instituto de Direito do Trabalho, vol. III, Coimbra, 2002, p. 473-534, MARIA DO ROSÁRIO PALMA RAMALHO, Tratado de Direito do Trabalho, Parte II, ...cit., p. 635, e PEDRO ROMANO MARTINEZ, Direito do Trabalho ...cit., p. 993. No que tange à jurisprudência e no sentido de que o prazo de prescrição só começa a contar-se após a prática do último acto, ver Ac. STJ de 8 de Junho de 2006, processo n. ${ }^{\circ} 05$ S3731, disponível em www.dgsi.pt, Ac. STJ de 24 de Janeiro de 2007, processo n. ${ }^{\circ} 06$ S3854, disponível em e o Ac. RP de 2 de Junho de 2008 , processo n. ${ }^{\circ} 0747109$, disponível em www.dgsi.pt.

${ }^{70}$ Neste sentido NUNO ABRANCHES PINTO, Instituto Disciplinar Laboral ...cit., p. 125

${ }^{71}$ Idem, ...cit., p. 127.

${ }^{72}$ Contra esta interpretação PEDRO FURTADO MARTINS, Cessação do Contrato de Trabalho ...cit., p. 199.
} 
alegar e provar os factos de onde se conclua a inobservância dos prazos pelo empregador ${ }^{33}$.

\subsection{0 prazo [de caducidade ou de prescrição] para iniciar o procedimento disciplinar}

0 segundo prazo que o legislador estabelece, e que o empregador tem de considerar no exercício da acção disciplinar, é o que está previsto no n. ${ }^{\circ} 2$ do artigo $329 .^{\circ}$ CT. Este prazo diz respeito ao início da acção disciplinar pelo empregador.

Dispõe a norma que o procedimento disciplinar deve iniciar-se nos 60 dias subsequentes àquele em que o empregador, ou o superior hierárquico com competência disciplinar, teve conhecimento da infraç̧ão. Da leitura da norma extrai-se que, enquanto o empregador ou 0 superior hierárquico não tiverem conhecimento dos factos ou elementos que compõe a infracção disciplinar cometida pelo trabalhador, este prazo não começa a correr. Neste contexto, é especialmente relevante a identificação autor da infracção ${ }^{74}$.

Perante a falta de tomada de posição do legislador quanto à natureza deste prazo, diferentemente do sucede nos n. ${ }^{0} 1$ e 3 deste artigo, em que os qualificou como prazos de prescrição, a doutrina tem-se debruçado sobre esta questão. 0 tema tem sido alvo de discussão.

Assim, e para uma grande parte da doutrina este prazo para o empregador dar início ao procedimento, após ter conhecimento da infracção é um prazo de caducidade, nos termos do previsto no artigo $298 .{ }^{\circ}$ n. ${ }^{\circ} 2$ do Código Civil $^{25}$.

A qualificação deste prazo de 60 dias como prazo de caducidade assenta essencialmente em duas ordens de razões ${ }^{76}$. Em primeiro lugar atenta a natureza supletiva do critério da norma do n. ${ }^{0} 2$ do artigo $298 .^{\circ}$ CC, que se aplica sempre que a lei não previr solução diversa.

Acresce que a qualificação da acção disciplinar do empregador como um direito potestativo, cujo exercício fica sujeito ao instituto da caducidade, por contraposição à prescrição que se verifica nos direitos subjectivos. Este é o outro argumento para quem defende que se trata de um prazo de caducidade.

Diferentemente para aqueles autores que consideram o prazo referido como um prazo de prescrição invocam especialmente o argumento de que os prazos de caducidade não admitem causas de suspensão ou interrupção. 0 que sucede nomeadamente com este prazo por efeito do envio da nota de culpa ao trabalhador ou com a instauração do inquérito prévio, conforme previsto no artigo $353 .^{\circ} \mathrm{n} .{ }^{0} 3 \mathrm{CT}^{7 ?}$.

No que respeita à jurisprudência, na qualificação que os tribunais tem feito do prazo tem predominado a sua caracterização como prazo de caducidade ${ }^{78}$. Levantando-se igualmente a

\footnotetext{
${ }^{73}$ Neste sentido, entre outros, decidiram os Acórdãos do STJ de 13 de Outubro de 2010, in CJ (STJ), 2010, III, p. 254-260, e Ac. STJ de 18 de Fevereiro de 2011, in CJ (STJ), 2011, I, p. 252-257.

${ }^{74}$ Considerando que não basta o conhecimento genérico das infracções, impondo-se também a identificação do trabalhador que as cometeu, assim decidiu o STJ no Ac. de 13 de Julho de 2004, processo n. ${ }^{\circ} 03 S 3476$ disponível em www.dgsi.pt, e Ac. de 12 de Setembro de 2007 , processo n. ${ }^{\circ} 07 \mathrm{~S} 1698$, disponível em www.dgsi.pt.

${ }^{75}$ Assim o consideram entre outros, MARIA DO ROSÁRIO PALMA RAMALHO, Tratado de Direito do Trabalho, Parte II, ...cit., p. 653, e MARIA ADELAIDE DOMINGOS, Poder e Procedimento Disciplinar no Código do Trabalho ...cit., p.487.

${ }^{76}$ Sobre os conceitos de prescrição e caducidade ver MANUEL DE ANDRADE, Teoria Geral da Relação Jurídica, Volume II, Almedina, Coimbra, 1992 , p. 445 e 463.

${ }^{7}$ Neste sentido PEDRO SOUSA MACEDO, Poder Disciplinar Patronal, ...cit., p. 116, NUNO ABRANCHES PINTO, Instituto Disciplinar Laboral ...cit., p. 119 e PEDRO ROMANO MARTINEZ, Código do Trabalho Anotado ...cit., p. 699.

${ }^{78}$ Veja-se neste sentido o Ac. STJ Uniformizador de Jurisprudência 4/2003 de 21 de Maio de 2003, processo n. ${ }^{\circ} 025452$, disponível em www. dgsi.pt. E também ao Ac. RL de 25 de Junho de 2006, processo n. ${ }^{\circ} 0746048$, disponível em www.dgsi.pt e o Ac. STJ de 13 de Janeiro de 2010 , processo n. ${ }^{0}$ 1321/06.4 TTLSB.L1.S1, disponível em www.dgsi.pt que consideraram que a caducidade do procedimento disciplinar só se interrompe no dia em que o trabalhador arguido é notificado da nota de culpa, sendo irrelevante que o procedimento disciplinar tenha sido ordenado antes da comunicação da nota de culpa.
} 
questão acerca do conhecimento oficioso deste prazo ${ }^{79}$.

No caso do despedimento, se o empregador exercer o poder disciplinar para além do prazo referido, o despedimento será ilícito, nos termos do artigo $382 .{ }^{\circ}$ n. ${ }^{0} 1 \mathrm{CT}$.

\subsection{0 prazo de prescrição do procedimento disciplinar}

Com as alterações do Código do Trabalho em 2009, introduzidas pela mão da Lei n. ${ }^{07 / 2009}$ de 12 de Fevereiro, acabou por se consagrar na lei um prazo que garante efectivamente a celeridade e a imediação do procedimento disciplinar. Refira-se aliás, que no domínio da lei anterior, e à falta da consagração de prazo idêntico considerava-se que o empregador no exercício da acção disciplinar estava apenas vinculado a deveres de celeridade e diligência.

Actualmente o legislador submete o exercício da acção disciplinar do empregador ao cumprimento de um outro prazo que introduziu no n. ${ }^{\circ} 3$ do artigo $329 .^{\circ} \mathrm{CT}$.

Esta norma passou a fixar um prazo máximo de duração do procedimento disciplinar. Dispõe que o procedimento disciplinar prescreve decorrido um ano da data em que é instaurado quando, nesse prazo, o trabalhador não seja notificado da decisão final.

No caso do despedimento, e atendendo à natureza receptícia da comunicação da decisão de despedimento, importa notar que a contagem deste prazo principia com o início do procedimento e termina quando o trabalhador recebe a decisão final do despedimento prevista no artigo $357 .{ }^{\circ} \mathrm{n}^{\circ} \mathrm{P}$ CT.

Diferentemente da solução que o legislador preconizou para a inobservância pelo empregador dos prazos referidos no n. ${ }^{0} 1$ e 2 deste artigo, conclui-se que o não cumprimento do prazo de um ano para conclusão do procedimento disciplinar não determina a ilicitude do despedimento. Convém referir que não se encontram razões que justifiquem esta opção do legislador.

\subsection{0 prazo de caducidade para aplicação das sanções disciplinares}

No que tange ao prazo para aplicar a sanção, o n. ${ }^{\circ} 2$ do artigo $330.0^{\circ} \mathrm{CT}$ estabelece um prazo segundo o qual a sanção deve ter lugar nos três meses subsequentes à decisão da sua aplicação, sob pena de caducidade ${ }^{80}$.

A qualificação deste prazo como de caducidade verificou-se a partir das alterações introduzidas no Código do Trabalho em 2009.

A consagração deste prazo pelo legislador tem levantado na doutrina algumas dúvidas no que respeita à sua aplicação à sanção de perda de dias de férias. A dificuldade pode surgir num caso concreto, em que o trabalhador já tenha marcado as suas férias e o empregador não as possa alterar, ou em que o trabalhador não disponha de férias no ano em curso, casos em que a execução da sanção no prazo referido pode não ser viável.

Há na doutrina quem admita a não sujeição do empregador ao cumprimento deste prazo neste caso específico e outros há, que por sua vez não admitem esta argumentação ${ }^{81}$. A discussão

\footnotetext{
${ }^{79} 0$ Acórdão Uniformizador de Jurisprudência n. ${ }^{\circ}$ 4/2003 de 21 de Maio de 2003 referido na nota anterior, decidiu que não constitui matéria de conhecimento oficioso do tribunal a caducidade do procedimento disciplinar.

${ }^{80}$ Sobre o tema ver Ac. STJ de 30 de Abril de 2013, processo n. ${ }^{\circ} 1154 / 09.6$ TTLSB.L1.S1, disponível em www. dgsi.pt, que decidiu que as diligências probatórias a partir das quais se começa a contar o prazo de caducidade do direito de aplicar a sanção não se circunscrevem àquelas que o trabalhador haja requerido na sua resposta à nota de culpa, mas abrangem também quaisquer outras que o instrutor do processo disciplinar entenda oficiosamente promover.

${ }^{81}$ Defendendo que o empregador não tem de cumprir neste caso concreto qualquer prazo, PEDRO ROMANO MARTINEZ, Código do Trabalho Anotado ...cit., p. 701. A posição contrária com a qual concordamos, é sufragada por MARIA DO ROSÁRIO PALMA RAMALHO, Tratado de Direito do Trabalho, Parte II, ...cit., p. 648 e JÚLIO MANUEL VIEIRA GOMES, Direito do Trabalho - Relações Individuais de Trabalho, Volume I ...cit., p. 897.
} 
não nos parece especialmente relevante visto que o empregador dispõe de um leque variado de sanções, podendo caso se frustre a aplicação desta sanção, escolher uma outra que se mostre igualmente adequada à punição do comportamento do trabalhador.

Genericamente tem-se entendido que a obrigação de aplicar a sanção num curto espaço de tempo é um corolário do princípio da boa fé na execução dos contratos ${ }^{82}$.

\section{0 procedimento para aplicação das sanções conservatórias: a audiência prévia do trabalhador}

Para aplicar qualquer das diversas sanções que não o despedimento, afere-se da lei que 0 empregador está obrigado a respeitar a audiência prévia do trabalhador.

Assim, e não obstante o artigo $329 .^{\circ}$ CT referir-se ao "procedimento" disciplinar, parece que só podemos falar num verdadeiro procedimento - realizado por escrito, e onde são identificáveis diversas fases quando o empregador pretenda despedir o trabalhador ${ }^{83}$. De outra forma, e para a aplicação das demais sanções não podemos falar num procedimento disciplinar.

0 procedimento disciplinar, como mais à frente referiremos, destina-se a assegurar a clareza e transparência da decisão assumida pelo empregador, ao mesmo tempo que garante ao trabalhador 0 direito a defender-se. A sua elaboração faculta ainda a possibilidade de sindicar eficazmente a aplicação das sanções disciplinares.

Para aplicar qualquer das outras sanções que não o despedimento não se colhe da lei que 0 empregador tenha de realizar qualquer procedimento por escrito ${ }^{84}$.

Em defesa desta ideia, aliás, o n. ${ }^{\circ} 6$ do artigo $329 .{ }^{\circ}$ CT dispõe que a sanção disciplinar não pode ser aplicada sem audiência prévia do trabalhador ${ }^{85}$.

0 cumprimento desta regra, obriga portanto o empregador a ouvir o trabalhador antes de the aplicar qualquer sanção conservatória.

Não se colhe da leitura da lei que o empregador tenha de cumprir outras formalidades, como por exemplo, que esteja obrigado, nestas situações, a deduzir a acusação do trabalhador por escrito, e que para além de o ouvir lhe permita apresentação da sua defesa por escrito.

Admitimos porém que a realização por escrito do procedimento serve não só para demonstrar a utilização conforme à lei e não abusiva do poder disciplinar do empregador. Admitimos até, e em certa medida, que a realização deste procedimento por escrito, protege o empregador ${ }^{86}$. De facto, como pela prática nos é permitido concluir, muitos empregadores utilizam o procedimento disciplinar nos exactos termos que a lei fixa para o despedimento, mesmo quando se trata de aplicar as sanções conservatórias, o que se verifica particularmente à medida que a gravidade da sanção vai aumentando.

Importa referir que perante as sanções previstas na lei dificilmente se possa defender que a aplicação da sanção de repreensão esteja sujeita a um procedimento escrito, porque, nesta situação, a isso se opõe a natureza verbal e imediata desta sanção ${ }^{87}$.

\footnotetext{
${ }^{82}$ Como considera JÚLIO MANUEL VIEIRA GOMES, Direito do Trabalho - Relações Individuais de Trabalho, Volume I ...cit., p. 889.

${ }^{83}$ BERNARDO DA GAMA LOBO XAVIER, Procedimentos na empresa para uma visão procedimental do Direito do Trabalho, in Revista de Direito e de Estudos Sociais, 2007, n.s ${ }^{\circ} 1$ e 2, p. 42, define o procedimento "como sequência de actos estabelecidos nas normas de trabalho e por estas normas regulados com vista à realização de um acto final, no procedimento também compreendido".

${ }^{84}$ Neste sentido, posição com a qual concordamos, ANTÓNIO MONTEIRO FERNNADES, Direito do Trabalho ...cit., p. 231.

${ }^{85} \mathrm{Se} 0$ empregador não respeitar a audiência prévia do trabalhador comete uma contra-ordenação grave, prevista no artigo $554 .^{\circ} \mathrm{CT}$.

${ }^{86}$ JÚLIO MANUEL VIEIRA GOMES, Direito do Trabalho - Relações Individuais de Trabalho, Volume I ...cit., p. 896, considera que o procedimento deve ser feito por escrito para impedir o uso arbitrário de tal poder pelo empregador.

${ }^{87}$ MARIA DO ROSÁRIO PALMA RAMALHO, Tratado de Direito do Trabalho, Parte II, ...cit., p. 652, defende que a aplicação de qualquer sanção ao trabalhador deve ser precedida de um processo, posição que nos parece excessiva face à letra da lei.
} 
Sobre o procedimento com vista a aplicar a sanção de despedimento trataremos mais à frente neste trabalho, pelo que para lá remetemos.

\section{Os mecanismos de controlo da aplicação de sanções disciplinares}

Aplicada a sanção ao trabalhador pode o mesmo reagir judicial ou extrajudicialmente. De acordo com o disposto no n. ${ }^{\circ} 7$ do artigo $329 .{ }^{\circ} \mathrm{CT}$, o trabalhador pode reclamar para o escalão hierarquicamente superior ao que aplicou a sanção, assim como, recorrer a processo de resolução de litígio desde que previsto na lei ou em IRCT.

\subsection{A reclamação interna}

A admissibilidade da reclamação contra uma sanção que tenha sido aplicada ao trabalhador trata-se de uma forma de procurar resolver este assunto no seio da empresa, evitando nomeadamente o litígio judicial quanto à aplicação de sanções disciplinares ${ }^{88}$.

Esta solução é de muito interesse, em especial por permitir "satisfazer" os interesses em questão sem recurso ao litígio judicial, o que em regra representa a hostilização das relações entre trabalhador e empregador.

Contundo, nos termos em que a reclamação aparece prevista na lei, pressupõe antes de mais, que o trabalhador se insira numa organização, e que essa organização esteja ordenada de forma hierarquizada.

Sucede que o legislador laboral não desenvolveu a figura, para além da breve referência em que manifesta a sua admissibilidade. Não há previsão de regra quanto ao prazo em que a reclamação deva ser apresentada pelo trabalhador, assim como, se a utilização deste mecanismo suspende os prazos para a impugnação judicial, o que em todo o caso, nos parece não ser possível.

A reclamação suscitada pelo trabalhador pode ser atendida pelo superior hierárquico e, consequentemente diminuída ou extinta a responsabilidade disciplinar do trabalhador. Já não nos parece que por via da reclamação se possa agravar a sanção inicialmente aplicada.

\subsection{A impugnação judicial das sanções conservatórias}

0 trabalhador a quem tenha sido aplicada uma sanção que considere ilegal, e sem prejuízo da correspondente reclamação pode atacá-la através da impugnação judicial prevista no artigo 329. ${ }^{\circ} .^{\circ}$ 7 CT.

Para acautelar eficazmente os seus direitos, o trabalhador pode igualmente lançar mão, se assim o entender, do procedimento cautelar comum (32. ${ }^{\circ}$ e ss CPT) com vista a "impedir" a execução da sanção disciplinar que Ihe foi aplicada pelo empregador ${ }^{89}$.

Impõe-se notar neste âmbito, que se a sanção aplicada for o despedimento o trabalhador dispõe de mecanismos processuais próprios, quer com vista à impugnação, quer quanto à suspensão do despedimento, e que trataremos separadamente neste trabalho. A ser assim, o que faz sentido por agora é determo-nos sobre os mecanismos judiciais ao dispor do trabalhador para impugnar as outras sanções que the sejam aplicadas, que não sejam o despedimento. A acção judicial para obtenção da impugnação judicial da sanção será intentada junto do tri-

\footnotetext{
${ }^{88}$ Embora a lei não o diga expressamente este meio adequa-se às sanções conservatórias, pois no que tange ao despedimento o legislador referiu expressamente a necessidade de o impugnar judicialmente.

${ }^{89}$ Importa referir que o recurso do trabalhador a qualquer destes mecanismos não suspende os prazos de que o empregador dispõe para execução das sanções e a que já nos referimos.
} 
bunal do trabalho territorialmente competente ${ }^{90}$. Contudo, dada a ausência de acção própria para este fim, o trabalhador terá de impugnar a sanção socorrendo-se do processo declarativo comum, previsto nos artigos $51 .^{\circ}$ e ss do CPT, e se for o caso, verificados os pressupostos relativos ao procedimento cautelar comum, nos termos do artigo $32 .^{\circ} \mathrm{CPT}$.

A principal questão em torno da impugnação judicial das sanções conservatórias aplicadas ao trabalhador prende-se com o prazo de que o trabalhador dispõe para o fazer, isto porque o legislador não o estabeleceu.

A falta de tratamento legislativo desta matéria faz com que a posição mais difundida na doutrina seja aquela que considera que o trabalhador deve poder impugnar a sanção que Ihe foi aplicada pelo seu empregador, dentro do mesmo prazo em que pode impugnar o despedimento ${ }^{91}$. Posição essa que encontramos também subscrita em diversos acórdãos. Na essência mandase aplicar por analogia a esta acção, o prazo para a impugnação do despedimento, (o que até à criação da nova acção de impugnação de regularidade e licitude do despedimento) era exclusivamente o prazo geral de prescrição dos créditos previsto no n. ${ }^{\circ} 1$ do artigo $337 .{ }^{\circ} \mathrm{CT}$ - um ano contado desde da data da cessação do contrato de trabalho ${ }^{92}$. Os argumentos que presidem à extensão do prazo de um ano a estas situações, são genericamente os mesmos que se invocam quanto ao despedimento, e que consideram que o trabalhador só tem "liberdade" para reagir contra o empregador quando a relação de trabalho acaba.

Contudo a aplicação deste prazo às situações de impugnação de sanções diferentes do despedimento é tudo menos linear, sendo-lhe apontadas diversas críticas.

Desde logo, a aplicação do mesmo prazo de que o trabalhador dispõe para impugnar o despedimento pode parecer excessiva quando se trata de impugnar sanções conservatórias. A aplicação deste prazo condiciona os efeitos dos actos do empregador relativos à competência disciplinar, que no limite, vários anos volvidos desde a sua aplicação, poderiam vir a ser impugnados no ano seguinte ao da cessação do contrato de trabalho.

Sucede que, e em desfavor da aplicação do prazo referido existe a questão da conservação das provas, que como é sabido se vão perdendo com a passagem do tempo. Pelo que a ser assim, a previsão de um prazo tão vasto também não se revela especialmente útil.

Porém a falta de solução legal tem feito da solução referida, e não obstante as críticas, a mais aplicada no que tange ao prazo de impugnação das sanções que não despeçam o trabalhador. Impõe-se actualmente uma referência ao prazo de 60 dias previsto para a acção especial para impugnação da regularidade e licitude do despedimento. Este prazo de 60 dias para o trabalhador impugnar o despedimento conta-se a partir da data da recepção da decisão do despedimento e está previsto no n. ${ }^{\circ} 2$ do artigo $387 .{ }^{\circ} \mathrm{CT}$. A questão que hoje faz sentido colocar é a de saber se esta acção especial, e este prazo de 60 dias contados após a recepção

\footnotetext{
${ }^{90}$ De acordo com o previsto na alínea b) do artigo $118 .^{\circ}$ da LOFTJ, os tribunais do trabalho tem competência em matéria cível para conhecer de todas as questões emergentes de relações de trabalho subordinado.

${ }^{91}$ Neste sentido ALBINO MENDES BAPTISTA, Prazo de impugnação judicial do despedimento. A propósito do Ac. do STJ de 7.2.2007, in Temas de Direito do Trabalho e de Direito Processual do Trabalho, Livraria Petrony, Lisboa, 2008, p. 153 e ABÍLIO NETO, Processo disciplinar e despedimentos ...cit., p. 20, PEDRO ROMANO MARTINEZ, Direito do Trabalho ...cit., p. 641 e JOÃO LEAL AMADO, Uma questão interessante: de que prazo dispõe o trabalhador para impugnar judicialmente uma sanção disciplinar?, in Reflexões, 2007, n. ${ }^{\circ 2}$, p. 22. Diferentemente ANTÓNIO JORGE DA MOTTA VEIGA, Lições de Direito do Trabalho ...cit., p. 345 refere que o prazo que o trabalhador tem para impugnar a sanção deve ser o mesmo prazo de que o empregador dispõe para a aplicar.

${ }^{92}$ Sobre a questão do prazo para impugnar sanções disciplinares que não o despedimento, Ac STJ de 22 de 0utubro de 2008 , processo n. ${ }^{\circ}$ 07S3787, disponível em www. dgsi.pt, Ac. STJ de 6 de Dezembro de 2011, processo n. ${ }^{0}$ 338/08.9TTLSB.L1.S1, disponível em www.dgsi.pt e Ac. STJ de 16 de Maio de 2012, processo n. ${ }^{\circ}$ 3982/06.5TTLSB.L1.S1, disponível em www.dgsi.pt.
} 
da decisão que comunica ao trabalhador a aplicação de uma sanção conservatória, poderão ser uma opção a aplicar analogicamente à impugnação das sanções disciplinares diferentes do despedimento.

Não nos parece no entanto poder ser esta uma solução, nem este prazo aquele que se deva considerar para o trabalhador impugnar judicialmente a sanção que o empregador lhe aplicou. Parece-nos, por um lado, um prazo demasiado curto, e que o legislador previu porque o trabaIhador não precisa de "intentar" uma verdadeira acção, bastando-lhe entregar no tribunal um requerimento e a decisão de despedimento. E por outro lado, nesta acção, o ónus da prova é do empregador, regra que, quando o trabalhador pretende impugnar uma sanção conservatória não se deve aplicar ${ }^{93}$.

Pelo exposto, perante a lacuna que referimos propendemos para aplicar o prazo de prescrição do $337 .{ }^{\circ}$ n. ${ }^{0} 1 \mathrm{CT}$ às situações de impugnação judicial de sanções conservatórias.

Importa ainda referir que a eventual decisão do tribunal que reconheça a ilicitude da sanção aplicada, condiciona apenas o empregador a alterar a sanção, isto porque pertencendo o poder disciplinar ao empregador, não poderá o tribunal decidir pela aplicação de outra sanção. Da análise realizada foi-nos permitido concluir que a falta de conceitos, ou noutras situações, a utilização de conceitos vagos e indeterminados, e a não tipificação das infracções adensam as dificuldades do empregador no que tange à qualificação das infracções e à escolha da sanção adequada. Em todo o caso garante-se sempre a audiência prévia do trabalhador e o direito de sindicar internamente ou judicialmente as sanções conservatórias que lhe sejam aplicadas.

\section{BIBLIOGRAFIA}

AMADO, João Leal, Uma Questão Interessante: De que Prazo dispõe o Trabalhador para Impugnar Judicialmente uma Sanção Disciplinar?, Reflexões, 2007, n. ${ }^{\circ 2}$, p. 9-23.

AMADO, João Leal, Impugnação Judicial de Despedimento e Reclamação de Créditos Laborais: o mesmo prazo?, Questões Laborais, 2007, n. ${ }^{\circ 30}$, p.251-254.

AMADO, João Leal, Contrato de Trabalho, 3. a edição, Coimbra Editora, Coimbra, 2013.

BAPTISTA, Albino Mendes, Jurisprudência do Trabalho Anotada, 3. a edição, Quid Juris Sociedade Editora, Lisboa, 1999.

BAPTISTA, Albino Mendes, Estudos Sobre o Código do Trabalho, Coimbra Editora, 2. ${ }^{a}$ edição, Coimbra, 2006.

BAPTISTA, Albino Mendes, Prazo de Impugnação Judicial do Despedimento. A propósito do Ac. do STJ de 7.2.2007, Temas de Direito do Trabalho e de Direito Processual do Trabalho, Livraria Petrony, Lisboa, 2008, p. 111- 154.

BAPTISTA, Albino Mendes, A Nova Acção de Impugnação do Despedimento e a Revisão do Código de Processo do Trabalho, Wolters Kluwer/ Coimbra Editora, Coimbra, 2010.

CORDEIRO, António Menezes, Concorrência Laboral e Justa Causa de despedimento, Revista da Ordem dos Advogados, 1986, n. ${ }^{\circ} 2$, p. 495-527.

CORDEIRO, António Menezes, Manual de Direito do Trabalho, Almedina, Coimbra, 1991.

CORDEIRO, António Menezes, 0 Respeito pela Esfera Privada do Trabalhador, António Moreira (Coord.) I Congresso Nacional de Direito do Trabalho - Memórias, Almedina, Coimbra, 1998, p. 19-37.

CORDEIRO, António Menezes, A Liberdade de Expressão do Trabalhador, António Moreira (Coord.) II Congresso Nacional de Direito do Trabalho - Memórias, Almedina, Coimbra, 1999, p. 21-43.

CORDEIRO, António Menezes, Justas Causas de Despedimento, Estudos do Instituto do Direito do Trabalho, Vol. II., Almedina, Coimbra, 2001, p.7-14.

DOMINGOS, Maria Adelaide, Poder e Procedimento Disciplinar no Código do Trabalho, Centro de Estudos Judiciá-

\footnotetext{
${ }^{93}$ Contra NUNO ABRANCHES PINTO, Instituto Disciplinar Laboral ...cit., p. 139, defende que nas acções de impugnação de sanções conservatórias o ónus da prova recai sobre o empregador.
} 
rios (coord.), A Reforma do Código do Trabalho, Coimbra Editora, Coimbra, 2004, p. 475-493.

DOMINGOS, Maria Adelaide, Poder e Procedimento Disciplinar: Algumas Alterações Introduzidas pelo Código de 2009, Código do Trabalho - A Revisão de 2009, Coimbra Editora, Coimbra, 2011, p. 453-466.

FERNANDES, António Monteiro, As Sanções Disciplinares e a sua Graduação, Estudos Sociais e Corporativos, n. ${ }^{0} 36,1970$, p. 23-54.

FERNANDES, António Monteiro, A Natureza da Infracção Disciplinar, Estudos Sociais e Corporativos, n. ${ }^{019}$, 1966, p. 29-47.

FERNANDES, António Monteiro, As Formas de Cessação do Contrato de Trabalho no Novo Código, António Moreira (Coord.), VI Congresso Nacional de Direito do Trabalho - Memórias, Almedina, Coimbra, 2004, p. 195-202.

FERNANDES, António Monteiro, Sobre a Serventia do Processo Disciplinar Laboral, Revista de Direito e de Estudos Sociais, 2004, p. 187-212.

FERNANDES, António Monteiro, A Justa Causa de Despedimento na Constituição e na Lei. Ensaio em torno de um tema antigo, in Prontuário de Direito do Trabalho, Centro de Estudos Judiciários, n. ${ }^{\circ} 87$, Coimbra Editora, 2010, p. 219-250.

FERNANDES, António Monteiro, Direito do Trabalho, 16. a edição, Almedina, Coimbra, 2012.

GOMES, Júlio Manuel Vieira, Deve o Trabalhador Subordinado Obediência a Ordens llegais?, Trabalho e Relações Laborais, Cadernos Sociedade e Trabalho, n. ${ }^{01}$, Oeiras, 2001, p. 179-187.

GOMES, Júlio Manuel Vieira, Algumas Reflexões sobre as Faltas Justificadas por Doença (não profissional) do Trabalhador, Estudos de Homenagem ao Prof. Doutor Raúl Ventura, Vol. II, Coimbra Editora, Coimbra, 2003, p. $717-749$.

GOMES, Júlio Manuel Vieira e CARVALHO, Raquel, Código do Trabalho - A (in) constitucionalidade) das Normas Relativas à Repetição do Procedimento Disciplinar e à Reintegração, Questões Laborais, n. ${ }^{0} 22,2003, \mathrm{p}$. 212-223.

GOMES, Júlio Manuel Vieira, Direito do Trabalho, Volume I - Relações Individuais de Trabalho, Coimbra Editora, Coimbra, 2007.

GONÇALVES, Manuel Maia, Código Penal Anotado, Almedina, Coimbra, 17. a edição, 2005.

LAMBELHO, Ana e GONÇALVES, Luísa Andias, Poder Disciplinar, Justa Causa de Despedimento, Quid Juris Sociedade Editora, Lisboa, 2012.

LEITÃo, Luis Manuel Teles de Menezes, A Proteç̧ão dos Dados Pessoais no Contrato de Trabalho, Centro de Estudos Judiciários (coord.), A Reforma do Código do Trabalho, Coimbra Editora, Coimbra, 2004, p. 123-138.

LEITÃo, Luis Manuel Teles de Menezes, Direito do Trabalho, 3. a edição, Almedina, Coimbra, 2012.

LEITÃo, Maria da Glória e NOBRE, Diogo Leote, Código do Trabalho Revisto - Anotado e Comentado, Lisboa, Vida Económica, 2009.

LEITE, Jorge, Direito do Trabalho, Volume II, reimp., Serviços de Acção Social da Universidade de Coimbra, Coimbra, 2004.

LEITE, Jorge, Código do Trabalho - Algumas Questões de (in) constitucionalidade, Questões Laborais, n. ${ }^{\circ} 22$, 2003, p. 245-278.

MACEDO, Pedro Sousa, Poder Disciplinar Patronal, Almedina, Coimbra, 1990.

MARECOS, Diogo Vaz, Prática e Procedimentos do Processo Disciplinar - do Mero Instrutor ao Advogado Instrutor, Principia, Estoril, 2007.

MARECOS, Diogo Vaz, Código do Trabalho Anotado. Lei n. ${ }^{07} / 2009$ de 12 de Fevereiro, Wolters Kluwer Coimbra Editora, Coimbra, 2010.

MARTINEZ, Pedro Romano, A Justa Causa de Despedimento, António Moreira (Coord.) I Congresso Nacional de Direito do Trabalho - Memórias, Almedina, Coimbra, 1998, p. 171-180.

MARTINEZ, Pedro Romano, Poder de Direcção: Âmbito do Poder Disciplinar: Desrespeito de Ordens. Comentário ao Ac. STJ de 20/10/1999, Revista de Direito e de Estudos Sociais, Agosto - Dezembro, 2000, p. 385-408.

MARTINEZ, Pedro Romano, Incumprimento Contratual e Justa Causa de Despedimento, Estudos do Instituto de Direito do Trabalho, Vol. II, Almedina, Coimbra, 2001, p. 93-118.

MARTINEZ, Pedro Romano, A Reforma do Código do Trabalho: Perspectiva Geral, Centro de Estudos Judiciários (coord.), A Reforma do Código do Trabalho, Coimbra Editora, Coimbra, 2004, p. 31-44.

MARTINEZ, Pedro Romano, Apontamentos sobre a Cessação do Contrato de Trabalho à luz do Código do Trabalho, Associação Académica da Faculdade de Direito de Lisboa, Lisboa, 2005.

MARTINEZ, Pedro Romano, 0 Código do Trabalho e a Reforma de 2012. Apreciação Geral, Revista de Direito e de Estudos Sociais, ano LIII, n. ${ }^{\circ}$ s 1-2, Janeiro - Junho de 2012, p. 11-20. 
MARTINEZ, Pedro Romano, et.al. Código do Trabalho Anotado, 9. a edição, Almedina, Coimbra, 2013.

MARTINEZ, Pedro Romano, Direito do Trabalho, 6. ${ }^{a}$ edição, Almedina, Coimbra, 2013.

MARTINS, Pedro Furtado, Despedimento Ilícito, Reintegração na Empresa e Dever de Ocupação Efectiva, Direito e Justiça - Revista da Faculdade de Direito da Universidade Católica Portuguesa, Universidade Católica Portuguesa, Lisboa, 1992.

MARTINS, Pedro Furtado, Consequências do Despedimento llícito: Indemnização/Reintegração, Código do TrabaIho, Alguns Aspectos Cruciais, Centro de Estudos do Trabalho, Universidade Católica Portuguesa, Principia, Cascais, 2003, p. 49-61.

MARTINS, Pedro Furtado, Cessação do Contrato de Trabalho, 3. a edição, Principia Editora Lda, Cascais, 2012.

MORAIS, Domingos José, A Cessação do Contrato de Trabalho por Iniciativa do Empregador, Centro de Estudos Judiciários (coord.), A Reforma do Código do Trabalho, Coimbra Editora, Coimbra, 2004, p. 503-536.

MORAIS, Domingos José, 0 Poder e o Procedimento Disciplinar, Código do Trabalho - A Revisão de 2009, Coimbra Editora, Coimbra, 2011, p. 395-407.

MOREIRA, Teresa Coelho, 0 Respeito pela Esfera Privada do Trabalhador: Natureza Jurídica das Faltas Cometidas por Motivo de Prisão baseada em Crimes praticados fora do trabalho, Questões Laborais, n. ${ }^{0} 8,2001, \mathrm{p}$. 155-189.

MOREIRA, Teresa Coelho, Da Esfera Privada do Trabalhador e do Controlo do Empregador, Studia Juridica, Coimbra, Coimbra Editora, 2004.

MOREIRA, Teresa Coelho, Intimidade do Trabalhador e Tecnologia Informática, António Moreira [Coord.] VII Congresso Nacional de Direito do Trabalho - Memórias, Almedina, Coimbra, 2004, p. 175-192.

NETO, Abílio, Código de Processo do Trabalho Anotado, 5. ${ }^{a}$ edição., Ediforum, Lisboa, 2011.

NETO, Abílio, Novo Código do Trabalho e Legislação Complementar Anotados, 3. a edição, Ediforum, Lisboa, 2012.

NOBRE, Diogo Leote, A Relevância dos Comportamentos Extra-Laborais em Sede de Justa Causa de Despedimento, Revista da Ordem dos Advogados, ano 68, Setembro/Dezembro, 2008, pp. 923-960.

PINTO, Nuno Abranches, Instituto Disciplinar Laboral, Coimbra Editora, Coimbra, 2009.

RAMALHO, Maria do Rosário Palma, Do Fundamento do Poder Disciplinar Laboral, Almedina, Coimbra, 1993.

RAMALHO, Maria do Rosário Palma, Sobre os Limites do Poder Disciplinar Laboral, António Moreira [Coord.] I Congresso Nacional de Direito do Trabalho - Memórias, Almedina, Coimbra, 1998, p. 181-198.

RAMALHO, Maria do Rosário Palma, Os Limites do Poder Disciplinar Laboral, Estudos de Direito do Trabalho, Vol. I, Almedina, Coimbra, 2003, p. 179-193.

RAMALHO, Maria do Rosário Palma, 0 Direito da Igualdade do Código do Trabalho: Contributo para uma reflexão, Centro de Estudos Judiciários (coord.), A Reforma do Código do Trabalho, Coimbra Editora, Coimbra, 2004, p. $173-190$.

RAMALHO, Maria do Rosário Palma, Tratado de Direito do Trabalho, Parte I - Dogmática Geral, 3. a edição, Almedina, Coimbra, 2012.

RAMALHO, Maria do Rosário Palma, Tratado de Direito do Trabalho, Parte II - Situações Laborais Individuais, 4 a $^{\text {a }}$ edição, Almedina, Coimbra, 2012.

RAMALHO, Maria do Rosário Palma, Tratado de Direito do Trabalho, Parte III - Situações Laborais Colectivas, Almedina, Coimbra, 2012.

SILVA, Maria Manuela Maia, 0 Tempo no Processo Disciplinar, António Moreira (Coord.) I Congresso Nacional de Direito do Trabalho - Memórias, Almedina, Coimbra, 1998, p. 199-222.

VEIGA, António Jorge da Motta, Lições de Direito do Trabalho, 8. a edição, Universidade Lusíada, Lisboa, 2000.

XAVIER, Bernardo da Gama Lobo, Justa Causa de Despedimento: Conceito e Ónus da Prova, Revista de Direito e de Estudos Sociais, n. ${ }^{0} 1,1988$, p.1-6?.

XAVIER, Bernardo da Gama Lobo, A Extinção do Contrato de Trabalho, Revista de Direito e de Estudos Sociais, 1989, n. ${ }^{\circ} 3$ e 4, p. 399-482.

XAVIER, Bernardo da Gama Lobo, Prescrição da Infracção Disciplinar, Revista de Direito e de Estudos Sociais, XXXII, 1990, p. 225-26?.

XAVIER, Bernardo da Gama Lobo, et al., Cessação Factual da Relação de Trabalho e Aplicação do Regime Jurídico do Despedimento, Revista de Direito e de Estudos Sociais, 1999, n. ${ }^{01}$, p. 41-49.

XAVIER, Bernardo da Gama Lobo, Procedimentos na Empresa para uma Visão Procedimental do Direito do TrabaIho, Revista de Direito e de Estudos Sociais, 2007, n. ${ }^{0} 1$ e 2, p. 23-78.

XAVIER, Bernardo da Gama Lobo, Prescrição nas Relações de Trabalho, Revista de Direito e de Estudos Sociais, Julho - Dezembro - 2012, Almedina, Coimbra 2013, p. 7-42. 